\title{
A Comparison of Form-Focused and Meaning-Focused Instruction Types: A Study on Ishik University Students in Erbil, Iraq
}

\author{
Bünyamin Celik ${ }^{1}$ \\ ${ }^{1}$ Department of Languages, Ishik University, Erbil, Iraq \\ Correspondence: Bünyamin Celik, Department of Languages, Ishik University, Erbil, Iraq. E-mail: \\ bunyamin.celik@ishik.edu.iq
}

Received: September 24, 2018 Accepted: October 18, 2018 Online Published: December 29, 2018

doi:10.5539/ijel.v9n1p201

URL: https://doi.org/10.5539/ijel.v9n1p201

\begin{abstract}
Form-focused and meaning-focused instruction types entered the literature after the 1970s as a reaction to each other. More interestingly, there is a cycle of reactions to each other, which claim to complete the other's shortcomings. In the middle of long-lasting discussions, this study aims to contribute to the field by making a comparison of the two terms. This research on students was done throughout seven weeks and the results were noted down. At the beginning of the survey, we applied an FCE test as pre-test and another FCE test at the end of the seven-week period as post-test. The underlying idea of such long survey is that we expect that in upper-intermediate level, students are in need of instructions from the teachers because the topics are much more complex than previous levels. During the survey, one group was given meaning -focused instruction and the other group was given form-focused instruction. The achievement of the students was measured both on vocabulary and grammar. At the end of seven weeks, both the grammar/vocabulary quiz results and the FCE results indicated a crucial difference on the development of two groups' proficiency levels thanks to form-focused instruction.
\end{abstract}

Keywords: form-focused instruction, meaning-focused instruction, communicative approaches, natural approach, focus on form, focus on forms

\section{Introduction}

Human history abounds with long-lasting debates between two or more traditions in every field. Generally the latter observes some problems of the former and corrects them. That is also true for foreign language education. The anachronistic methods of grammar translation were not suitable for changing world in 1970s and there was a movement against it to correct and make the language learning more suitable for the contemporary needs. But later, some drawbacks of the reactionary method brought about another reaction, which justified the idea mentioned above in the paragraph. Meaning-focused instruction and form-focused instruction developed in the same atmosphere and inherited much to today's researchers.

\section{Historical Background}

If one has a quick look at the historical background, it will emerge that communicative approach was already at issue in 1970s, and later it strongly influenced English Language Teaching (ELT) and had an important role shaping the next decades of ELT (Lamb, 1995, p. 72). One argument says that teaching grammar explicitly is impossible because the knowledge of grammar for speaking too complex to acquire. Another approach which says teaching grammar is unnecessary argues that the knowledge of grammar is something that cannot be passed in form of rules but can only be acquired unconsciously by being exposed to the language very much (Krashen, 1998, p. 10).

This approach became so ubiquitous that it was practically used by teachers extremely commonly. The reason behind it was not only attractiveness of this method to teachers but also a reaction against the old methods that heavily emphasize on teaching grammar at the expense of communication which should be main focus while teaching. The syllabi prepared under the effect of communicative approach put forth the objectives which mainly focused on what learners would learn about the functions of the language and very little or none emphasis on grammar. Although there were people who always reminded that grammar is inevitable part even with communicative approach to teach communication effectively, their voices were drowned out by the 
attractiveness of this method (Thompson, 1996, p. 10).

The main assumption that was developed in this method is that the four skills (reading, listening, writing, speaking) should be main focus and the language should be directly related to daily life and the needs to be met during lifetime experiences (O’Sullivan, 2001, p. 52).

What made this approach so successful throughout these mentioned time periods were that firstly it was applied in western countries where the method was applied by native English speakers to non-natives who were studying English in their countries, and secondly, those students always had the opportunity to hear and use English outside the school environment which was directly corresponding to the aims of Communicative Approach (O'Sullivan, 2001, p. 53). A third reason could be added that their native languages were already very akin to English as far as the sentence structure and vocabulary are concerned. Canagarajah (1996, p. 81) points out this issue in the review of Adrian Holliday's book "Appropriate Methodology and Social Context" and says: "First of all, the communicative approach has been criticized for ignoring some of the problematic issues behind unequal discourses in the relationship between English and other languages."

It could be better to trace the effects of a movement in sources aiming public like theater, cinema, advertisements and such things. They sometimes give a clearer picture about the effects rather than scientific sources. As it was stated above, the new paradigms in foreign language teaching prevailed the 1970s and the effects were easily discerned in movies. As an example, it would be better to have a look at the series "Mind Your Language" season 1 episode 2 (1977). The film was produced by London Weekend Television and directed by Stuart Allen. In this episode, the course administrator, Miss Courtney, informs Mr. Brown that a new African student will join their class. At the same time, she also tells him that a new inspector is about to come to supervise their course. Later, Mr. Kenyon, the inspector, comes and says that he will walk around on his own to get a clearer picture. When he enters Mr. Brown's class, he mistook the inspector with as the African student. The inspector tries to explain who he is but when he realizes that it is better to see around as a student, he disguises himself as a participant and sits down. When Mr. Brown comes to write his name into the register, he starts to talk negatively about the inspectors. There, Mr. Kenyon, as the disguised inspector, urges him to talk more. Mr. Brown says that the old-fashioned inspectors expect them to teach some grammar rules but it is better to teach the students some practical things like ordering meal and shopping. Later, they realize that this guy is the inspector and Miss Courtney enters the class. She says that Mr. Brown will severely be punished but the inspector likes his revolutionary ideas. Even he says that he will get across these ideas to the authorities to revise their books. Lastly, he praises Mr. Brown and recommends him to keep up the good work. Here is the script of the related part from the episode:

Mr. Brown: There's an inspector from the local Education Authority coming round.

Ali Nadim: The big boss.

Mr. Brown: Yes, I suppose you could say that. But from my experience they're usually interfering old fogies.

Inspector: You don't like them?

Mr. Brown: Not particularly! Frankly, they're quite useless and they are as outdated as their teaching methods. I mean, what is the point of learning past participles, Cognate objects or subordinate clauses? Far more useful to try to teach foreign students how to order a meal or find accommodations.

Inspector: You appear to have some unique ideas.

Mr. Brown: I suppose I have. You know you speak English fairly well.

Inspector: Thank you.

Mr. Brown: What is your name?

Inspector: Roger Kenyon!

Mr. Brown: Roger Kenyon. Ah Miss Courtney! I'm just completing the register and getting the details of our new student before that inspector chappie pokes his nose in.

Miss Courtney: Oh, no! Mr. Brown!!!

Mr. Brown: I shan't be a moment Miss Courtney. What is your job?

Inspector: Inspector!

Mr. Brown: What local transport?

Inspector: Local Education Authority. 
Mr. Brown: 1 thought he was the new student.

Miss Courtney: The new student is a female.

Mr. Brown: Is she? You didn't tell me that.

Miss Courtney: My apologies Mr. Kenyon, I do assure you that Mr. Brown will be severely dealt with.

Inspector: I can't remember when 1 last enjoyed myself so much.

Miss Courtney: I beg your pardon - Enjoyed yourself?

Inspector: You know Miss. Courtney; your Mr. Brown is a remarkable man.

Mr. Brown: I am?

Miss Courtney: He is?

Inspector: Yes! His teaching methods may be revolutionary but they appear to work.

Miss Courtney: I've always encouraged my staff to be forward thinking.

Inspector: I'll pass on your comments to the Authority. Perhaps they'll revise their textbooks. Now if you'll excuse me, I must put in an appearance at the other classes. Very well! Keep up the good work, Mr. Brown (Allen, 1977). (https://www.youtube.com/watch? $v=$ Bsn3MT-5Yyo\&t=72s)

When Communicative Approach became successful to some extent in western countries, later it was applied to the third world and other countries. But since they were under different conditions, the effectiveness of the method was in question (Holliday, 1994).

Holliday (1994) did research in schools in Egypt to measure the effectiveness of communicative approaches in different contexts and concluded that this country was not appropriate for the methodology for several reasons. Firstly, the teachers in Egyptian understanding have a very dominant role and they are unexpectedly authoritarian. Secondly, he observed that students in Egypt and many developing countries are not given opportunity to question their teachers, which make the method fruitless in these countries (O'Sullivan, 2001, p. 53)

\section{Paradigm Shift}

Even when there are doubts about the method by the supporters of this approach, many others criticized different aspects and expressed their concerns in different ways. It was argued that when the supporters of the communicative approaches put forth the idea that learning process should not be affected by any interference by teacher and the rules and it should completely take place subconsciously, in fact they did not do necessary research on focusing on forms and they did not exactly observe the advantages of the latter. As a result, they just avoided the role of awareness, consciousness and attention. They went even further and took a position about syntax that consciousness has no role in teaching and they did not come up with any further comment as if they took the idea for granted (Doughty \& Williams, 1998, p. 275).

Later in the 1990s, there took place a dramatic paradigm shift and the communicative approaches were seen as inadequate to correspond to the needs of many students since much importance was given to meaning-focused activities. During this period, the inadequacies of the method were put forth and new solutions were offered. The experts started to emphasize more on focus on form and became the supporters of more principled and form-focused approaches (Nassaji, 2000, p. 242).

\section{Current Discussions}

First of all, it should be pointed out that there is not much research on these discrete forms of instruction. But there is a tendency that there should be a mixture of these two in different contexts and learning environments. It is now generally accepted that focusing on form and targeting the elucidation of meaning is to be followed, which is done in an integrated approach (Nassaji, 2000, p. 242). The exact reason behind choosing a way that entails both is that the both methods have their strong points and the weak ones at the same time. Those who are in part of meaning-focused instruction argue that the main focus of language teaching should be on communicative competence, and with the other way, the learners become unable to communicate in a desired way because they deal much with linguistic forms and thus lack in communication. On the other hand, meaning focused instruction has some other disadvantages over the former like lacking in developing an understanding of true structures (Göksu, 2014, p. 29).

As the literature developed in a way that puts forth the need to define more complicated occasions and offer solutions, new conceptions emerged. The history of the related terms shows the points to improve and the strng 
points, so current discussions are based on more complex terms to meet the needs. On the other hand, there are still clashes over some points such that while one approach (analytic) sees learning as a result of developing formal and rule-based knowledge and giving importance to controlled learning, the other approach (experiential) reckons learning as having a natural set of steps and thus emphasizes meaningful and message-based activities (Stern, 1992).

While some believe that form-focused instruction facilitates development (Larsen-Freeman and Long, 2014, 539), some others stipulate that meaning-focused activities improve the learners' skills necessary in communication much better (Nation, 2001, p. 473).

The current literature culminated in a peak where the combination of these two types of instruction has been endorsed. Although there are different concepts, they focus on the same thing. For instance, Long (1991) developed focus-on-form and focus-on-forms instructional types (Long, 1991, pp. 39-52) and Spada \& Lightbown (2008, pp. 181-207) offered isolated and integrated form-focused instruction.

\section{Related Literature}

After some decades of discussion, there emerged some key concepts, and some positive and negative sides of them are still at issue. Researchers of this field came up with definitions and their applications in different learning environments together with their strong and weak sides.

\subsection{Meaning-Focused Instruction}

The history of ideas is full of clashes and attempts of correction of previous notions. The same situation can be handled in second language instruction forms. But before that, there are some underlying ideas which provided a sound base for upcoming terminology. Thus, before mentioning meaning-focused instruction, it would be better to see the discussions in theoretical level that sheds light on the further explanations.

Krashen, as a pioneer of Natural Approach, argued that incidental learning is basis for learning a foreign or second language, like small children learning their mother tongue. In his "Input Hypothesis", Krashen puts forth that if learners are exposed to sensible amount of input on a regular basis, they will acquire the language in a desired way. When they are given extra information, they try to close the gap between what they know and what is put in front of them. In this way, they will get the language step-by-step (Krashen, 1985, p. 1).

If the students are exposed to comprehensible input, they will build up their acquisition of language in a natural order. In this way, Krashen differentiates between "acquisition" and "learning". In defending Natural Approach, he puts forth that learning, as a conscious process, serves as a monitor and learners make corrections and learn the rules. In order to eliminate the drawbacks of the old rule-based approaches, Krashen developed the Natural Approach and defended the natural way of acquiring a language (Krashen, 1985, p. 2).

After clearly determining the main goals of the communicative approaches, the main issue of how to promote acquiring a language was investigated more deeply and some solutions were offered:

1) They insist that the activities which include real communication urge the promotion of a language acquisition.

2) The activities with meaningful tasks promote learning.

3) If the given input is meaningful to the learner, it is reckoned to be promoting learning process (Richards \& Rogers, 1986).

Meaning-focused instruction was developed on the basis of communicative approaches and in fact, it was a reaction to traditional rule-based, grammar-bound teaching methods. In this sense, it could also be claimed that there was a kind of dissatisfaction with form-focused approaches which dominated the field previously. The developers of this terminology apparently detected a gap between what is taught in classroom environment and what skill are required communicatively (Celce-Muncia, Dornyei, \& Thurrell, 1997, p. 147).

Meaning-focused instruction can be defined as exposing learners to rich input of target language the use of it in context that causes incidental acquisition of it, in which learners apply a natural order that native speakers of a language follow during the time they acquire it (Long, \& Robinson, 1998).

Meaning-focused instruction was derived from the practical need of communicating effectively in real world. to achieve this goal, it was believed that the learners should be equipped with communicative strategies, and this idea developed into a position that the learners should not be bothered with the grammatical rules. It was also argued that accuracy in learning should not be focused at the beginning and thus the input would eventually enable the learners to acquire and produce the target language (Grim, 2005, pp. 20-21).

At this point, Krashen defends the idea that grammatical structures can already be learned through 
communicative activities because the learners just apply the structures into the communicative environment where every single bit of language makes sense. Even more, they interact with others, which contribute much more to acquiring. As long as the context is meaningful, a full-scale acquisition becomes possible (Gardner, \& Wood, 2009, pp. 30-43).

It was also asserted that communicative activities through meaning-focused instruction set the learners free to choose the structures according to their needs in communicative environment. It was theorized that the learners determine their own analysis of the needs and use language in parallel with these needs. In this way, they are exempt from having to choose right structure to use and follow any order of learning them. The prevailing idea here is that getting the message across effectively is much more important than actual use of the grammatical structures which correspond to the situation (Littlewood, 1980, pp. 441-445).

On the other hand, there are some drawbacks of the underlying approaches and the meaning-focused instruction. Firstly, many teachers complained that the syllabi on this basis were beyond their capacity to carry out. The teachers also note down that teaching in this method requires many significant resources that are not possible to meet in a learning environment. Secondly, the application of this method requires the teachers to have convenient education and to have a mindset adapted to the necessities of the method and the instruction. Even comprehending the rationale is a long-term job to do and it requires substantial education. But the teachers reported that they were not able to implement it since they were not well-equipped (O'Sullivan, 2001, p. 55)

Long (2000, p. 183) argues that focus on meaning suffers from some problems. He firstly points out to the drawback that the curriculum cannot be improved because there is generally no needs and means analysis. Secondly, he puts forth that there are many constraints regarding adult learners such that their innate abilities that they gained through their childhood and acquired their first language mostly hinders them from achieving native-like proficiency although they have adequate opportunity and motivation to learn. Thirdly, he also detected that some high achievers of Canadian French immersion programs got a level in their second language learning that it was statistically indistinguishable from native speakers, but still, their productive skills lagged much behind native speakers, especially of grammatical competence. Next, he focuses on a problem that was handled in this article above: The communicative approach supports generally applied their methods in western Europe where their native languages are somehow similar to English and they made much progress with their methods. But Long came up with just opposite results showing some first language interferences. The native speakers of French learning English in Canada made mistakes about the correct position of the adverbs in a sentence. From their French background, they construct such a sentence: "I drink every day coffee" which is grammatically wrong in English and should be as such: "I drink coffee every day." It should be underlined that the direct translation of this sentence into French as "Je bois toujours du café." is grammatically true. So he concludes that it is not possible to teach what i ungrammatical with this method. Lastly, he states that focusing only in meaning is not sufficient although it is necessary.

Another problematic point of meaning-focused instruction is reported as causing the learners to fossilize some wrong structures in the target language because they overgeneralize the rules of their mother tongue to the second language (Saeidi, Zaferanieh \& Shatery, 2012, p. 74). This is especially true of the languages that are quite alike in their structures like French and English.

\subsection{Form-Focused Instruction}

This is second type of instruction which was developed as a reaction to the previous one. "Form" refers to the grammatical and phonological features of language. It does not only refer to the form in traditional sense, in that, how to construct past tense in a language but also refers to the use of given structure. So both meaning and structure are included in the range of the term "form" (Ellis, 2001, 13). This instruction type is a broad term for the instructional activities that could be planned or incidental and is offered to the students to focus on the linguistic form. It includes the traditional structure teaching and the communicative approaches at the same time. $\mathrm{s}$ it is commonly used in the modern course books, the form is given in the activities where meaning focus is primarily intended (Ellis, 2001, 1-2). Yang and Lyster (2010, 235) emphasize that form-focused instruction has a huge difference from grammar translation methods in a way that the forms that are intended to be given are conveyed through communicative interaction and meaning-based tasks.

Different types of form-focused instruction was put forth by Spada \& Lightbown (2008, p. 186).

1) Isolated from-focused instruction: It means teaching a distinctive language feature with special focus separately from the communicative activities. It could be taught either before or after the communicative activity. The underlying idea here is that there are some difficult structures in the target language which require special attention because it is not easy to convey what it means through communication. In that case, 
the activity is isolated from any communicative aims and given distinctively. It is believed that some features are almost unlikely for the students to acquire through communicative activities and thus, isolated form-focused instruction is applied for the learners to grasp the form and meaning at the same time (Spada \& Lightbown, 2008, 186)

2) Integrated form-focused activities: Language forms or features integrate with communicative and content-based activities. The difference from the former one is that the language forms is not isolated from other activities and given in a mixed way and it is given with previously planned steps or it can pop up incidentally during lesson and interaction with others. The structure is mingled with communicative activities and the teacher can give a hand using corrective feedback. The form and function is emphasized at the same time but with minimum teacher interruption (Gündüz, Akcan \& Bayyurt, 2012, 159). But it should be stated that the primary Focus is always on meaning and incase students art in need of feedback and explanation of some grammar topics, then they are offered Help by the teachers in order for the learners to grasp the meaning more effectively and learn it more accurately especially through communicative interaction (Spada \& Lightbown, 2008, 186).

There have always been long-lasting discussions about teaching grammar in foreign language education. It can be stated that every approach that emerged in the field of foreign language teaching heard a word to say about grammar teaching. While some totally reject teaching grammar, some others, especially the traditional approaches, put special emphasis on teaching grammar. Even, as it was stated above, communicative approaches were a kind of reaction to the traditional grammar teaching ones, so they totally ignored it. Later it was seen that teaching with pure communicative activities led to some drawbacks and experts of the field follow a middle way to mingle both of them. Certainly, the supporters of form focused instruction developed their own terminology. Namely, they do a lot two approaches to grammar teaching: Focus-on-forms and Focus-on-form.

1) Focus-on-forms: In this teaching method of grammar, it is believed that separate linguistic units like words, grammar points, collocations...etc., are taught distinctively. The specific features are chosen and inserted in syllabus and they are taught in a systematic way. In fact, there is an intensive, teacher-centered application of the grammar features (Ellis, Basturkmen \& Loewen, 2002, 420). It just follows structural and syntactic components and teaches them one by one. The teacher presents grammar rules distinctly and explicitly, makes the students memorize short dialogues repeat some models in order to clarify one pre- selected item at a time (Long, 1991).

Sheen (2002, p. 304) points out that in this type, the focus is on understanding of the grammar and it is given in multiple ways, one of which is expressing the differences between L1 and L2. The exercises are to strengthen the grammar points and they could be given in either communicative or non-communicative activities. It also promotes the correct use of language (Sheen, 2002, 303-305).

On the other hand, Long (2000) detects several major drawbacks of this type. Firstly, he states that there is no identification of the communicative needs of the learners. The learning styles and the preferences of the learners are not prioritized. Secondly, dialogues to teach the grammar points are artificial and do not correspond to natural way of conversation. Thirdly, it is a behaviorist model ignores learning processes and thus, it was discredited long ago. The next problem is that it leaves the learners out of the syllabus design and so they do not actively decide their needs. Moreover, although there are efforts of teachers and many textbook writers, the lessons end up with boredom and students lose their motivation and attention (Long, 2000; p. 181-182).

2) Focus-on-form: In this type, lessons are designed to meet the communicative needs of the learners, and at the same time, the students' attention is drawn on some particular linguistic items. The main idea here is that students learn the language in a communicative environment and the main focus is on communication. But at the same time the linguistic items come out incidentally in the texts given and then the students are asked to extract the grammar points from there (Long, 1991, p. 45). It can also be defined as particular type of form focused instruction and it deals with a linguistic form in a context where's communicative activity is prioritized (Ellis, Basturkmen and Loewen, 2002, p. 419). Another definition states that focus-on-form is an attempt to balance meaning and form in a learning context where meaning has primary focus (Grim, 2005 , p. 13). Some characteristics of this type are as follows:

a) There is not passive learning and interaction between students is of primary importance. There is also observable behavior of the learners.

b) Using language communicatively has prior importance and linguistic elements emerge as peripheral points. 
c) It is broad-based and there may emerge different forms rather than one single chunk of grammar.

Focus-on-form was classified into two sub-categories according to how it is dealt in learning environment. Although it is handled as incidental and planned focus-on-form, both of them take place in communicative environment.

1) Incidental focus-on-form: The linguistic forms are not pre-determined and they emerge spontaneously during the lessons because the performance or the need of the learners determine what will be at issue. In this case, there is certainly extensive selection of forms because any of them may emerge at a time. In that sense, tasks are unfocused and general samples of language are dealt without any careful planning.

2) Planned focus-on-form: The communicative activities are specifically designed so as to involve pre-determined linguistic forms. The focused linguistic forms come out in parallel with what is planned previously. In contrast to the former, there is intensive selection of forms.

\section{Research Methodology}

\subsection{Design of the Study}

Quantitative methods have been used in this study because Quantitative analytical approaches make it possible to see the data results numerically. Numerical findings provide credibility of the study.

Learners firstly were given an FCE test as pre-test to measure their proficiency level. At the end of seven-week courses, they were again given another FCE test to measure how much they improved their English through extensive and intensive reading in upper-intermediate level. Both groups fulfilled the same weekly tests and quizzes simultaneously during seven-week course.

FCE (First Certificate in English) is an upper intermediate level examination and requires good vocabulary knowledge and it has five parts:

$\begin{array}{ll}\text { - } & \text { Reading } \\ \text { - } & \text { Uriting } \\ \text { - } & \text { Listening } \\ \text { - } & \text { Speaking }\end{array}$

Moreover, tests and quizzes were held in equal conditions - same duration, with well-lit and aired rooms, etc. Tests at the end of the graded readers were used in the weekly examinations and real FCE tests were applied. Professional-made test were chosen to provide the validity of testing results, as they all had been piloted.

The objective is to observe what kind of effect extensive reading with the meaning-focus instruction and intensive reading with the form-focus instruction have over vocabulary acquisition and mastering grammar structures in upper-intermediate English level.

The idea of giving two different FCE tests (the pre-test and the post-test,) to the learners was to track student progress in English. The scores the learners got in the tests gave an idea of how extensive reading or intensive reading promoted language learning in in upper-intermediate English level.

FCE tests involve different question types and reading and listening activities could be handled as the basic ones of all and they very clearly showed how the language learning process went on. Speaking and writing activities made it possible for the learners to reinforce the language they learned via intensive reading with form-focus instruction.

What urged us to do this study is that we previously did the same one in the doctoral dissertation (Çelik, 2016) and later we needed to do the same study on upper intermediate students. It is because of the reason that our dissertation indicated that there is not considerable difference between form-focused and meaning-focused instruction in pre-intermediate groups and that gave us the idea to use meaning-focused instruction more in all of the groups. But later, we realized that we did not get desired results in the exams and the students were not as proficient as they should have been. As a result, we applied this study to the chosen groups to get empirical data.

\subsection{Sample Selection}

The target population of this study is students and lecturers. For this study two groups were needed: control group and experimental group.

Ishik University Preparatory school students and lecturers participated in this study. All courses in departments at 
Ishik University are taught in English. After being admitted to Ishik University, learners have a placement test in the English language. The major goal of the placement test in English is to decide on their level of English.

Learners, depending on their scores of the placement test, are placed in different course levels. While beginner level learners study the essential knowledge in English through beginner level course books, upper-intermediate and advanced learners study language materials which are at a high level of proficiency. It was ensured that the language level of the learners in both control and experimental groups were more or less the same.

Two groups of learners were chosen randomly in my research after getting the required permission from the university administration and each group contained 20 learners so totally 40 students were selected in this research and also learners in both groups were selected from the same course level. The reading program for this study was a-seven-week program. While the experimental group had extensive reading program with meaning-focused instruction, intensive group learners had intensive reading program with form-focused instruction.

Selecting participants from the same level would be more convenient and more useful to obtain the best information. Learners were chosen randomly, no criteria were followed in forming the groups. Students were chosen spontaneously based on their own willingness; so, they were voluntary participants.

The students in both groups were formed from upper-intermediate level from five groups. The learners at upper-intermediate level in the study had been exposed to most of the general grammatical structures in English before they came to preparatory school at university, and they can understand the main ideas of complex text on both concrete and abstract topics, including technical discussions in his or her field of specialization.

In addition, the gender of the students and their ethnicity was another concern in this study. There was no discrimination of boys and girls and they were distributed in groups randomly. Moreover, there were international students. This study did not consider any difference in gender and ethnicity. The lecturer tried to have friendly bonds with the students and his role was to encourage the students to do their best.

Before the survey, the students were informed that some innovative approaches would be tested during the study. They were also assured that this study would not affect their academic performance. Furthermore, they were also assured that their personal results would not be shared with the third parties. During the study, some students showed the signs of stress and discomfort. The results of the weekly exams were used in this study. Some students did not get the scores they expected during some exams but their names were not shared with anybody else.

\subsection{Selection and Development of Material}

The learners were provided with approximately 500 English graded readers at different levels from series of Oxford, Cambridge and Penguin. The graded readers were at the Ishik University library. Learners returned finished books to the library and borrowed new ones. Learners chose the graded readers they enjoyed reading, and they were free to discontinue reading unless they liked the story.

They did not continue reading if it was difficult to understand either. Learners selected the books by genre, title, picture on the cover and mostly the number of pages in the book. But later learners recommended each other the books they liked. Every week learners in the experimental group read two graded readers and listened to them. They were also required to do reading comprehension questions of them.

The lecturer checked the exams and the wrong answers were corrected during checking. All of the students had their own files and the reading material that they covered was kept in their files. The lecturer also regularly held the records of what they learned, namely, he noted down the name of the book, genre and how many pages they covered. The lecturer also asked some questions to the students during office hours in order to check their comprehension.

Learners in the meaning focused group on the other hand read three graded readers in a week and listened to them. They also did reading comprehension questions and incorrect answers were immediately corrected. Moreover, for control purpose, during office hours learners retold their stories to the lecturer, and submitted a brief summary. They did the reading comprehension questions. Mostly questions at the end of the books were used. Their weekly quiz results were analyzed to follow up their achievement.

On the other hand, form focused group learners had one graded readers in a week. The same story was read by the learners and form focused instruction was applied. In other words learners had detailed reading in reading classes under the supervision of the lecturer. They had weekly quizzes as well and their scores were analyzed to follow up their achievement. 


\subsection{Procedure and Data Collection}

The first of the two groups was given meaning-focused instruction during seven weeks in their reading classes and it was chosen as experimental group. The second one, as the control group, was given form-focused instruction during these seven weeks. Roughly the same reading materials were given to the classes and equal time was spent for both of them. The group with meaning-focused instruction was exposed to meaningful use of the language and no form was underlined. In fact, they were told to study these things themselves. The activities covered:
1) True-false questions
2) Find the correct answer
3) Ask and answer the questions
4) Information gap
5) Minor and major ideas
6) Word meaning from the context
7) Inferences...etc.

The other group was provided with the linguistic elements and accuracy was given a special importance. They were asked to extract the grammatical forms from the text and to check unknown words and their usage from dictionaries. If they had any difficulty in comprehending the structure or the words, extra help was offered by the instructor. They also worked on the meaningful context and did the exercises that the other group was assigned to do.

The students in both groups were given tests at the end of every week.

\section{Findings}

\section{Week 1}

Table 1. Score of subjects in the experimental group with meaning-focused instruction

\begin{tabular}{lll}
\hline Name of the student & Grammar Quiz Results & Vocabulary Quiz Results \\
\hline Student 1 & 85 & 85 \\
Student 2 & 79 & 82 \\
Student 3 & 79 & 78 \\
Student 4 & 76 & 80 \\
Student 5 & 75 & 73 \\
Student 6 & 75 & 72 \\
Student 7 & 73 & 73 \\
Student 8 & 71 & 70 \\
Student 9 & 68 & 67 \\
Student 10 & 67 & 66 \\
Student 11 & 66 & 66 \\
Student 12 & 63 & 63 \\
Student 13 & 61 & 60 \\
Student 14 & 61 & 60 \\
Student 15 & 59 & 59 \\
Student 16 & 58 & 57 \\
Student 17 & 55 & 54 \\
Student 18 & 55 & 54 \\
Student 19 & 53 & 52 \\
Student 20 & 50 & 48 \\
\hline
\end{tabular}


Table 2. Score of subjects in the control group with form-focused instruction

\begin{tabular}{lll}
\hline Name of the student & Grammar Quiz Results & Vocabulary Quiz Results \\
\hline Student 1 & 90 & 91 \\
Student 2 & 90 & 90 \\
Student 3 & 85 & 89 \\
Student 4 & 85 & 85 \\
Student 5 & 81 & 85 \\
Student 6 & 82 & 83 \\
Student 7 & 77 & 77 \\
Student 8 & 77 & 76 \\
Student 9 & 76 & 74 \\
Student 10 & 76 & 74 \\
Student 11 & 73 & 74 \\
Student 12 & 73 & 70 \\
Student 13 & 70 & 69 \\
Student 14 & 69 & 69 \\
Student 15 & 69 & 65 \\
Student 16 & 65 & 65 \\
Student 17 & 65 & 65 \\
Student 18 & 65 & 61 \\
Student 19 & 61 & 61 \\
Student 20 & 61 & 58 \\
\hline
\end{tabular}

Table 3. Averages of grammar and vocabulary quizzes in both groups

\begin{tabular}{lll}
\hline Averages & Grammar Quiz Results & Vocabulary Quiz Results \\
\hline Meaning-focused instruction & 66.45 & 65.95 \\
Form-focused instruction & 74.50 & 74.05 \\
\hline
\end{tabular}

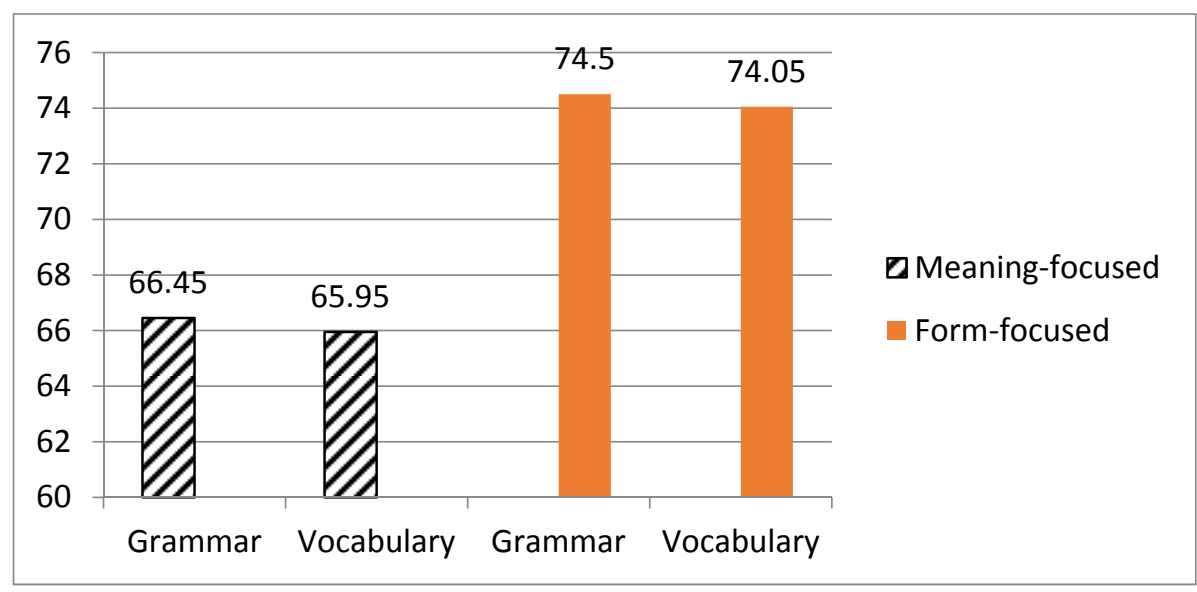

Figure 1. Averages of subjects in both groups

At the end of the first week, the students were given a test and the results indicated that the group with for-focus instruction achieves a bit higher than the other group. Although the distribution does not seem equal in the two groups, we did not make any changes because it is important here to see their development throughout the weeks. 


\section{Week 2}

Table 4. Score of subjects in the experimental group with meaning-focused instruction

\begin{tabular}{lll}
\hline Name of the student & Grammar Quiz Results & Vocabulary Quiz Results \\
\hline Student 1 & 83 & 82 \\
Student 2 & 80 & 77 \\
Student 3 & 79 & 77 \\
Student 4 & 77 & 74 \\
Student 5 & 75 & 74 \\
Student 6 & 75 & 75 \\
Student 7 & 71 & 75 \\
Student 8 & 71 & 69 \\
Student 9 & 67 & 65 \\
Student 10 & 67 & 62 \\
Student 11 & 67 & 67 \\
Student 12 & 65 & 64 \\
Student 13 & 63 & 63 \\
Student 14 & 62 & 61 \\
Student 15 & 59 & 58 \\
Student 16 & 59 & 58 \\
Student 17 & 55 & 59 \\
Student 18 & 55 & 56 \\
Student 19 & 56 & 56 \\
Student 20 & 55 & 50 \\
\hline
\end{tabular}

Table 5. Score of subjects in the control group with form-focused instruction

\begin{tabular}{lll}
\hline Name of the student & Grammar Quiz Results & Vocabulary Quiz Results \\
\hline Student 1 & 90 & 93 \\
Student 2 & 90 & 90 \\
Student 3 & 90 & 90 \\
Student 4 & 85 & 89 \\
Student 5 & 85 & 85 \\
Student 6 & 81 & 85 \\
Student 7 & 79 & 79 \\
Student 8 & 75 & 79 \\
Student 9 & 75 & 75 \\
Student 10 & 75 & 75 \\
Student 11 & 75 & 73 \\
Student 12 & 73 & 74 \\
Student 13 & 73 & 69 \\
Student 14 & 69 & 69 \\
Student 15 & 69 & 69 \\
Student 16 & 69 & 65 \\
Student 17 & 65 & 65 \\
Student 18 & 65 & 66 \\
Student 19 & 65 & 61 \\
Student 20 & 62 & 62 \\
\hline
\end{tabular}

Table 6. Averages of grammar and vocabulary quizzes in both groups

\begin{tabular}{lll}
\hline Averages & Grammar Quiz Results & Vocabulary Quiz Results \\
\hline Meaning-focused instruction & 67.05 & 66.1 \\
Form-focused instruction & 75.5 & 75.65 \\
\hline
\end{tabular}




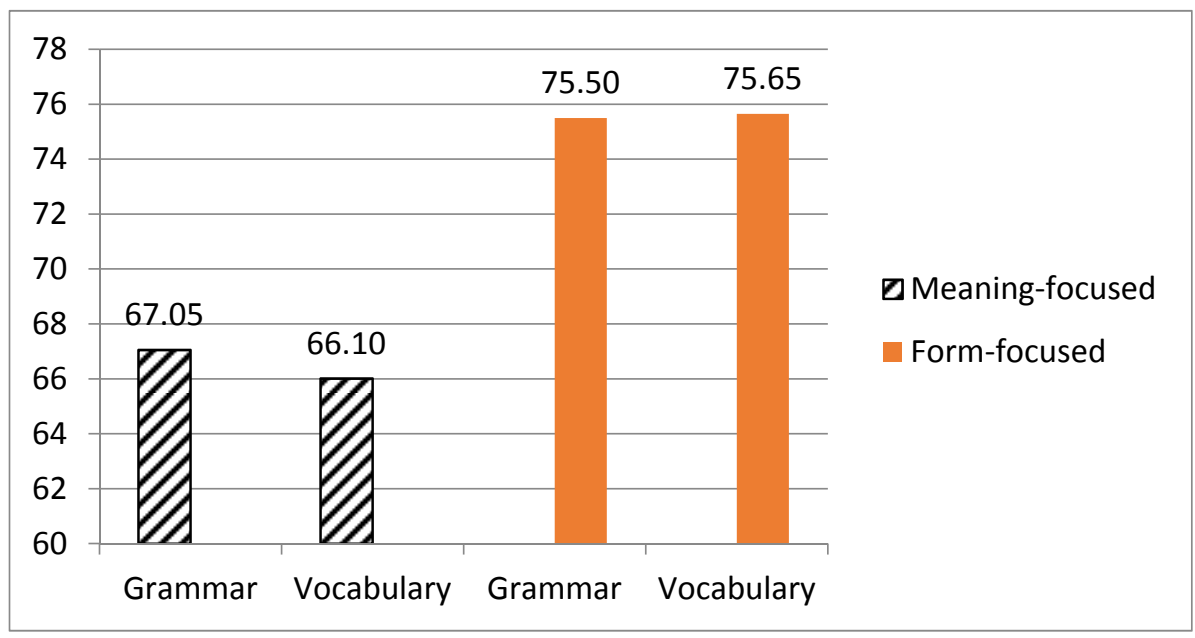

Figure 2. Averages of subjects in both groups

\section{Third Week}

Table 7. Score of subjects in the experimental group with meaning-focused instruction

\begin{tabular}{lll}
\hline Name of the student & Grammar Quiz Results & Vocabulary Quiz Results \\
\hline Student 1 & 83 & 84 \\
Student 2 & 80 & 82 \\
Student 3 & 78 & 80 \\
Student 4 & 76 & 78 \\
Student 5 & 76 & 72 \\
Student 6 & 75 & 71 \\
Student 7 & 75 & 75 \\
Student 8 & 71 & 70 \\
Student 9 & 67 & 70 \\
Student 10 & 65 & 69 \\
Student 11 & 68 & 63 \\
Student 12 & 67 & 62 \\
Student 13 & 66 & 69 \\
Student 14 & 63 & 60 \\
Student 15 & 57 & 56 \\
Student 16 & 56 & 57 \\
Student 17 & 52 & 59 \\
Student 18 & 56 & 59 \\
Student 19 & 54 & 55 \\
Student 20 & 51 & 55 \\
\hline
\end{tabular}


Table 8. Score of subjects in the control group with form-focused instruction

\begin{tabular}{lll}
\hline Name of the student & Grammar Quiz Results & Vocabulary Quiz Results \\
\hline Student 1 & 93 & 93 \\
Student 2 & 89 & 93 \\
Student 3 & 89 & 89 \\
Student 4 & 89 & 89 \\
Student 5 & 85 & 85 \\
Student 6 & 85 & 85 \\
Student 7 & 81 & 81 \\
Student 8 & 81 & 81 \\
Student 9 & 77 & 79 \\
Student 10 & 77 & 77 \\
Student 11 & 77 & 77 \\
Student 12 & 73 & 73 \\
Student 13 & 73 & 71 \\
Student 14 & 71 & 67 \\
Student 15 & 69 & 69 \\
Student 16 & 69 & 69 \\
Student 17 & 69 & 69 \\
Student 18 & 69 & 65 \\
Student 19 & 65 & 65 \\
Student 20 & 65 & 61 \\
\hline
\end{tabular}

Table 9. Averages of grammar and vocabulary quizzes in both groups

\begin{tabular}{lll}
\hline Averages & Grammar Quiz Results & Vocabulary Quiz Results \\
\hline Meaning-focused instruction & 66.8 & 67.3 \\
Form-focused instruction & 77.3 & 76.9 \\
\hline
\end{tabular}

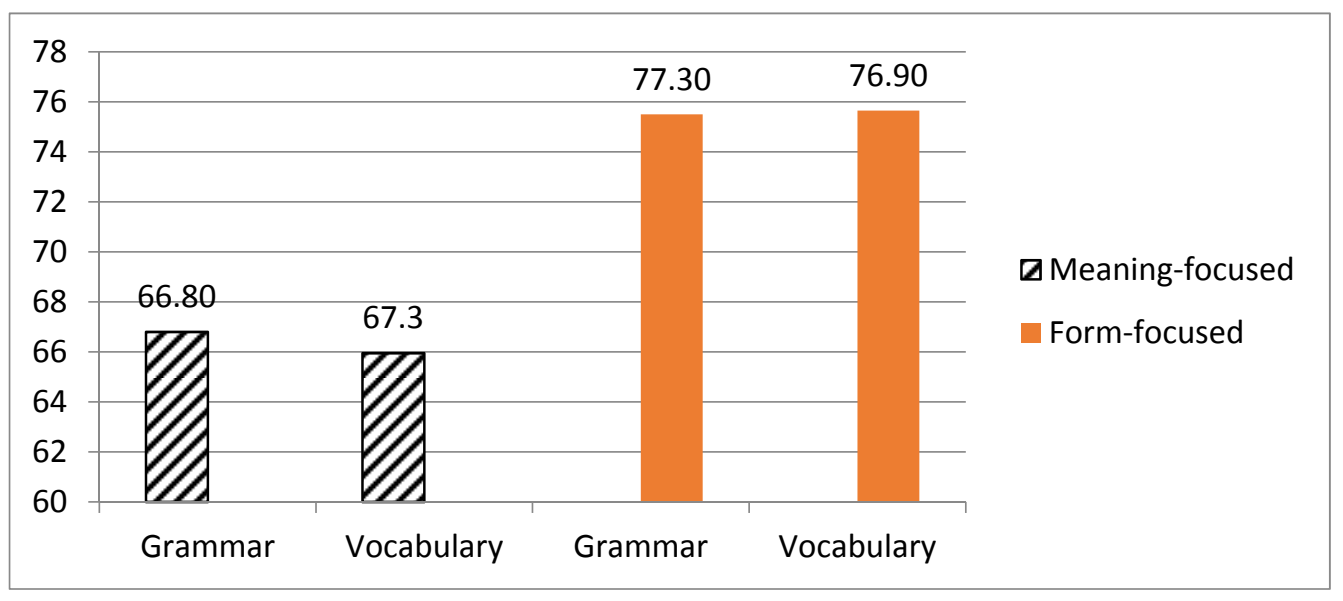

Figure 3. Averages of subjects in both groups 


\section{Fourth Week}

Table 10. Score of subjects in the experimental group with meaning-focused instruction

\begin{tabular}{lll}
\hline Name of the student & Grammar Quiz Results & Vocabulary Quiz Results \\
\hline Student 1 & 81 & 79 \\
Student 2 & 78 & 81 \\
Student 3 & 80 & 79 \\
Student 4 & 76 & 79 \\
Student 5 & 77 & 86 \\
Student 6 & 74 & 80 \\
Student 7 & 75 & 76 \\
Student 8 & 75 & 70 \\
Student 9 & 68 & 70 \\
Student 10 & 70 & 68 \\
Student 11 & 68 & 69 \\
Student 12 & 66 & 63 \\
Student 13 & 65 & 70 \\
Student 14 & 64 & 60 \\
Student 15 & 54 & 51 \\
Student 16 & 56 & 52 \\
Student 17 & 54 & 59 \\
Student 18 & 62 & 57 \\
Student 19 & 59 & 53 \\
Student 20 & 53 & 50 \\
\hline
\end{tabular}

Table 11. Score of subjects in the control group with form-focused instruction

\begin{tabular}{lll}
\hline Name of the student & Grammar Quiz Results & Vocabulary Quiz Results \\
\hline Student 1 & 93 & 93 \\
Student 2 & 93 & 93 \\
Student 3 & 89 & 89 \\
Student 4 & 89 & 89 \\
Student 5 & 89 & 89 \\
Student 6 & 85 & 85 \\
Student 7 & 85 & 85 \\
Student 8 & 79 & 79 \\
Student 9 & 79 & 79 \\
Student 10 & 77 & 81 \\
Student 11 & 77 & 77 \\
Student 12 & 77 & 75 \\
Student 13 & 73 & 73 \\
Student 14 & 73 & 73 \\
Student 15 & 73 & 73 \\
Student 16 & 73 & 69 \\
Student 17 & 68 & 69 \\
Student 18 & 68 & 69 \\
Student 19 & 68 & 65 \\
Student 20 & 64 & 65 \\
\hline
\end{tabular}

Table 12. Averages of grammar and vocabulary quizzes in both groups

\begin{tabular}{lll}
\hline Averages & Grammar Quiz Results & Vocabulary Quiz Results \\
\hline Meaning-focused instruction & 67.75 & 67.6 \\
Form-focused instruction & 78.6 & 78.5 \\
\hline
\end{tabular}




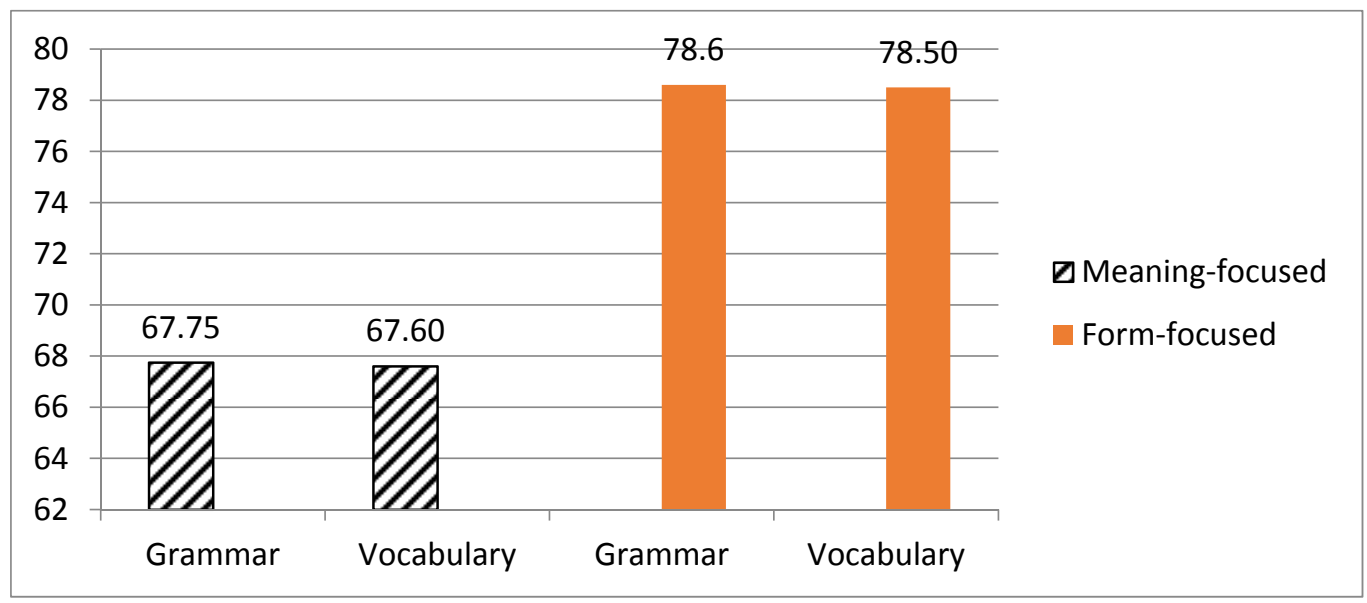

Figure 4. Averages of subjects in both groups

\section{Fifth Week}

Table 13. Score of subjects in the experimental group with meaning-focused instruction

\begin{tabular}{lll}
\hline Name of the student & Grammar Quiz Results & Vocabulary Quiz Results \\
\hline Student 1 & 85 & 84 \\
Student 2 & 81 & 81 \\
Student 3 & 78 & 80 \\
Student 4 & 75 & 74 \\
Student 5 & 71 & 72 \\
Student 6 & 74 & 77 \\
Student 7 & 79 & 79 \\
Student 8 & 75 & 72 \\
Student 9 & 65 & 70 \\
Student 10 & 67 & 70 \\
Student 11 & 71 & 70 \\
Student 12 & 67 & 62 \\
Student 13 & 65 & 71 \\
Student 14 & 65 & 62 \\
Student 15 & 56 & 60 \\
Student 16 & 54 & 58 \\
Student 17 & 57 & 60 \\
Student 18 & 60 & 56 \\
Student 19 & 54 & 57 \\
Student 20 & 57 & 49 \\
\hline
\end{tabular}

Table 14. Score of subjects in the control group with form-focused instruction

\begin{tabular}{lll}
\hline Name of the student & Grammar Quiz Results & Vocabulary Quiz Results \\
\hline Student 1 & 94 & 95 \\
Student 2 & 93 & 94 \\
Student 3 & 93 & 93 \\
Student 4 & 89 & 90 \\
Student 5 & 89 & 90 \\
Student 6 & 89 & 85 \\
Student 7 & 86 & 85 \\
Student 8 & 86 & 85 \\
Student 9 & 81 & 82 \\
Student 10 & 81 & 82 \\
Student 11 & 77 & 82 \\
Student 12 & 77 & 78 \\
Student 13 & 76 & 78 \\
Student 14 & 73 & 74 \\
Student 15 & 73 & 73 \\
Student 16 & 73 & 72 \\
Student 17 & 73 & 69 \\
Student 18 & 69 & 68 \\
Student 19 & 69 & 65 \\
Student 20 & 65 & 64 \\
\hline
\end{tabular}


Table 15. Averages of grammar and vocabulary quizzes in both groups

\begin{tabular}{lll}
\hline Averages & Grammar Quiz Results & Vocabulary Quiz Results \\
\hline Meaning-focused instruction & 67.8 & 68.2 \\
Form-focused instruction & 80.3 & 80.2 \\
\hline
\end{tabular}

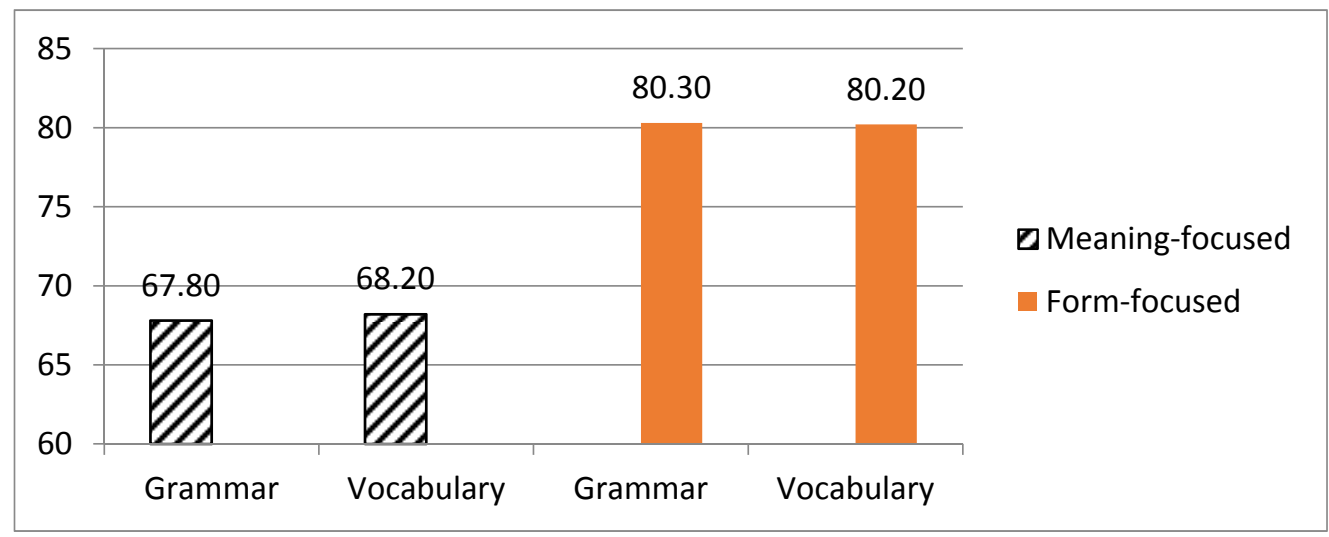

Figure 5. Averages of subjects in both groups

\section{Week 6}

Table 16. Score of subjects in the experimental group with meaning-focused instruction

\begin{tabular}{lll}
\hline Name of the student & Grammar Quiz Results & Vocabulary Quiz Results \\
\hline Student 1 & 88 & 88 \\
Student 2 & 88 & 88 \\
Student 3 & 88 & 88 \\
Student 4 & 84 & 84 \\
Student 5 & 84 & 84 \\
Student 6 & 84 & 84 \\
Student 7 & 80 & 84 \\
Student 8 & 80 & 80 \\
Student 9 & 76 & 80 \\
Student 10 & 76 & 80 \\
Student 11 & 72 & 76 \\
Student 12 & 72 & 76 \\
Student 13 & 72 & 72 \\
Student 14 & 72 & 72 \\
Student 15 & 68 & 68 \\
Student 16 & 68 & 68 \\
Student 17 & 68 & 64 \\
Student 18 & 64 & 64 \\
Student 19 & 64 & 64 \\
Student 20 & 60 & 60 \\
\hline
\end{tabular}


Table 17. Score of subjects in the control group with form-focused instruction

\begin{tabular}{lll}
\hline Name of the student & Grammar Quiz Results & Vocabulary Quiz Results \\
\hline Student 1 & 92 & 92 \\
Student 2 & 92 & 92 \\
Student 3 & 92 & 92 \\
Student 4 & 92 & 88 \\
Student 5 & 88 & 88 \\
Student 6 & 88 & 88 \\
Student 7 & 88 & 84 \\
Student 8 & 84 & 84 \\
Student 9 & 84 & 84 \\
Student 10 & 84 & 80 \\
Student 11 & 80 & 80 \\
Student 12 & 80 & 80 \\
Student 13 & 76 & 76 \\
Student 14 & 76 & 76 \\
Student 15 & 76 & 72 \\
Student 16 & 72 & 72 \\
Student 17 & 72 & 72 \\
Student 18 & 72 & 68 \\
Student 19 & 68 & 68 \\
Student 20 & 68 & 68 \\
\hline
\end{tabular}

Table 18. Averages of grammar and vocabulary quizzes in both groups

\begin{tabular}{lll}
\hline Averages & Grammar Quiz Results & Vocabulary Quiz Results \\
\hline Meaning-focused instruction & 67.8 & 68.2 \\
Form-focused instruction & 81.2 & 80.2 \\
\hline
\end{tabular}

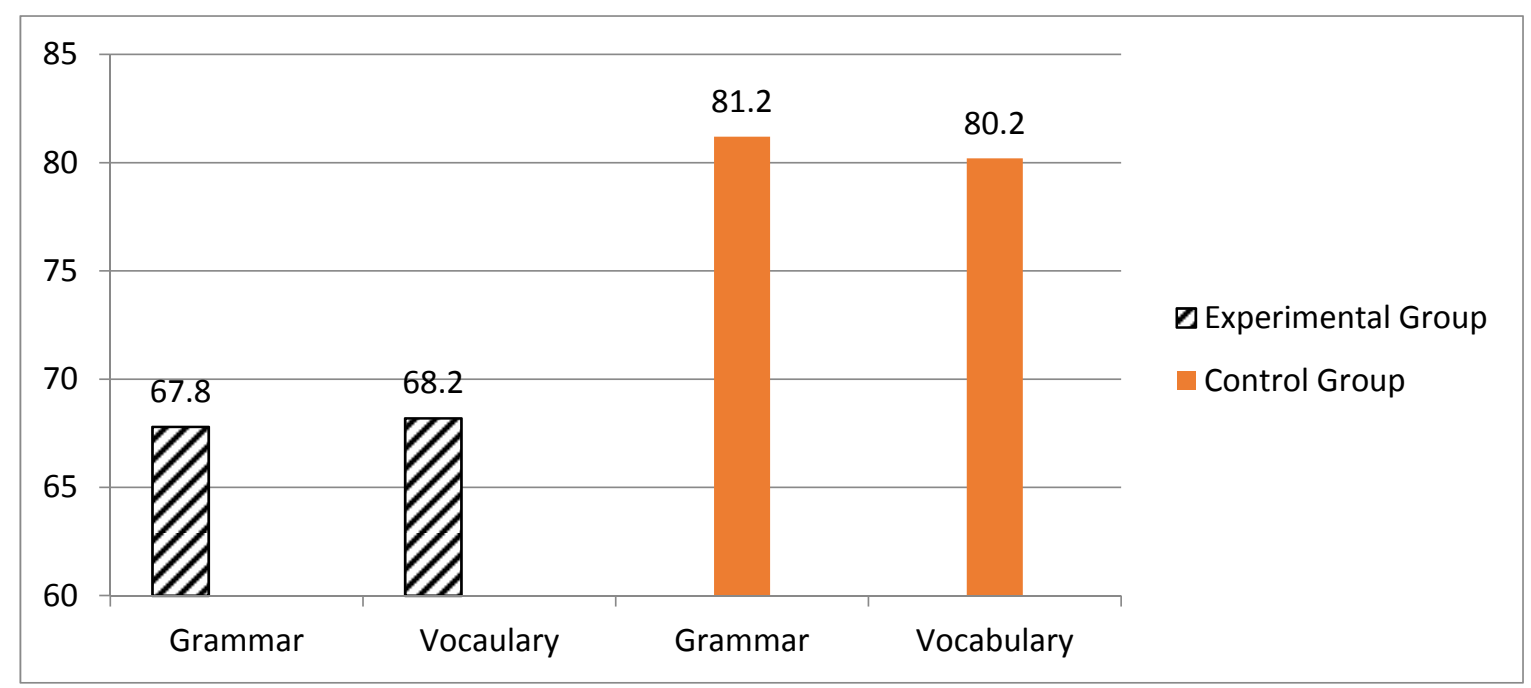

Figure 6. Averages of subjects in both groups 


\section{Week 7}

Table 19. Score of subjects in the experimental group with meaning-focused instruction

\begin{tabular}{lll}
\hline Name of the student & Grammar Quiz Results & Vocabulary Quiz Results \\
\hline Student 1 & 78 & 78 \\
Student 2 & 74 & 75 \\
Student 3 & 74 & 72 \\
Student 4 & 72 & 72 \\
Student 5 & 70 & 70 \\
Student 6 & 68 & 66 \\
Student 7 & 68 & 65 \\
Student 8 & 67 & 64 \\
Student 9 & 66 & 63 \\
Student 10 & 66 & 62 \\
Student 11 & 65 & 62 \\
Student 12 & 65 & 60 \\
Student 13 & 64 & 60 \\
Student 14 & 63 & 60 \\
Student 15 & 63 & 58 \\
Student 16 & 64 & 58 \\
Student 17 & 62 & 58 \\
Student 18 & 62 & 55 \\
Student 19 & 60 & 55 \\
Student 20 & 52 & 52 \\
\hline
\end{tabular}

Table 20. Score of subjects in the control group with form-focused instruction

\begin{tabular}{lll}
\hline Name of the student & Grammar Quiz Results & Vocabulary Quiz Results \\
\hline Student 1 & 96 & 96 \\
Student 2 & 96 & 96 \\
Student 3 & 92 & 96 \\
Student 4 & 92 & 88 \\
Student 5 & 88 & 88 \\
Student 6 & 88 & 88 \\
Student 7 & 88 & 84 \\
Student 8 & 88 & 84 \\
Student 9 & 84 & 84 \\
Student 10 & 84 & 84 \\
Student 11 & 84 & 80 \\
Student 12 & 80 & 80 \\
Student 13 & 80 & 80 \\
Student 14 & 76 & 76 \\
Student 15 & 76 & 76 \\
Student 16 & 76 & 76 \\
Student 17 & 72 & 72 \\
Student 18 & 72 & 72 \\
Student 19 & 72 & 72 \\
Student 20 & 72 & 72 \\
\hline
\end{tabular}

Table 21. Averages of grammar and vocabulary quizzes in both groups

\begin{tabular}{lll}
\hline Averages & Grammar Quiz Results & Vocabulary Quiz Results \\
\hline Meaning-focused instruction & 66.15 & 63.25 \\
Form-focused instruction & 82.8 & 80.20 \\
\hline
\end{tabular}




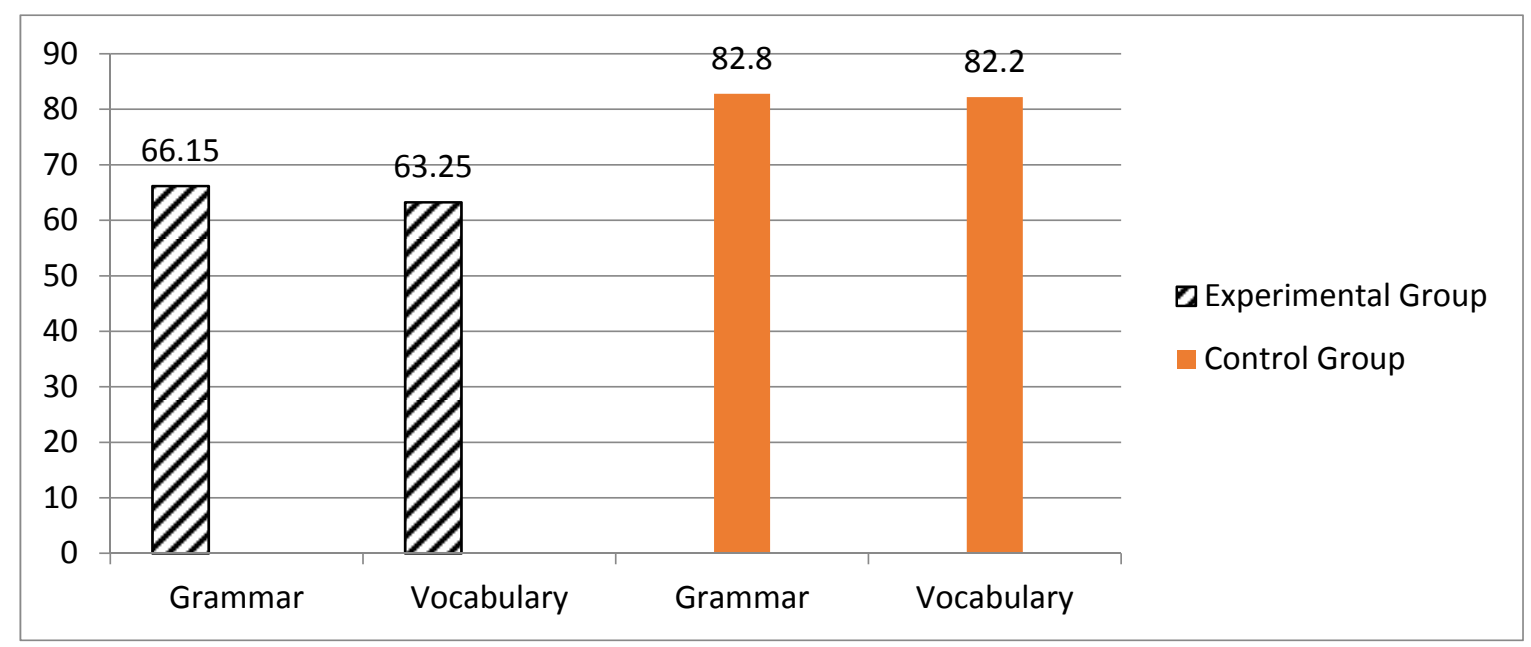

Figure 7. Averages of subjects in both groups

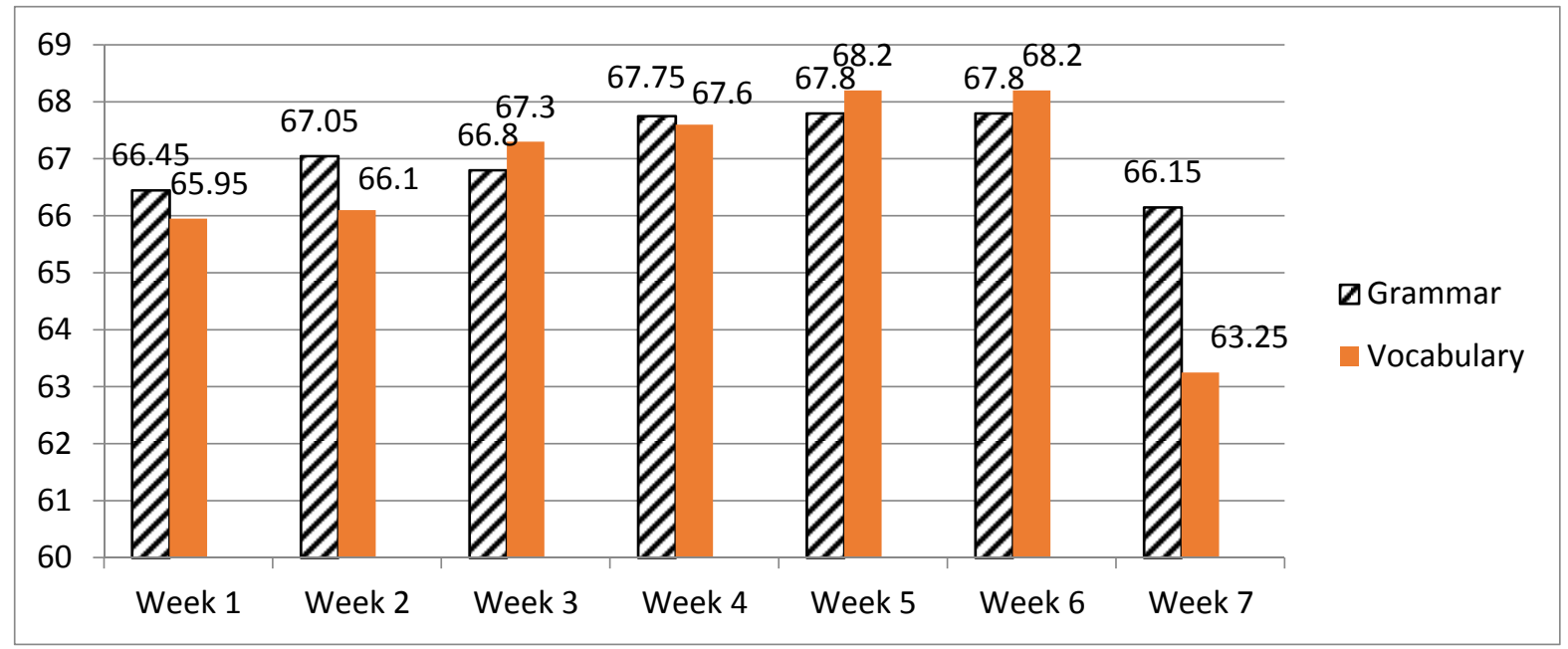

Figure 8. Averages of subjects in the experimental group with meaning-focused instruction in all weeks 


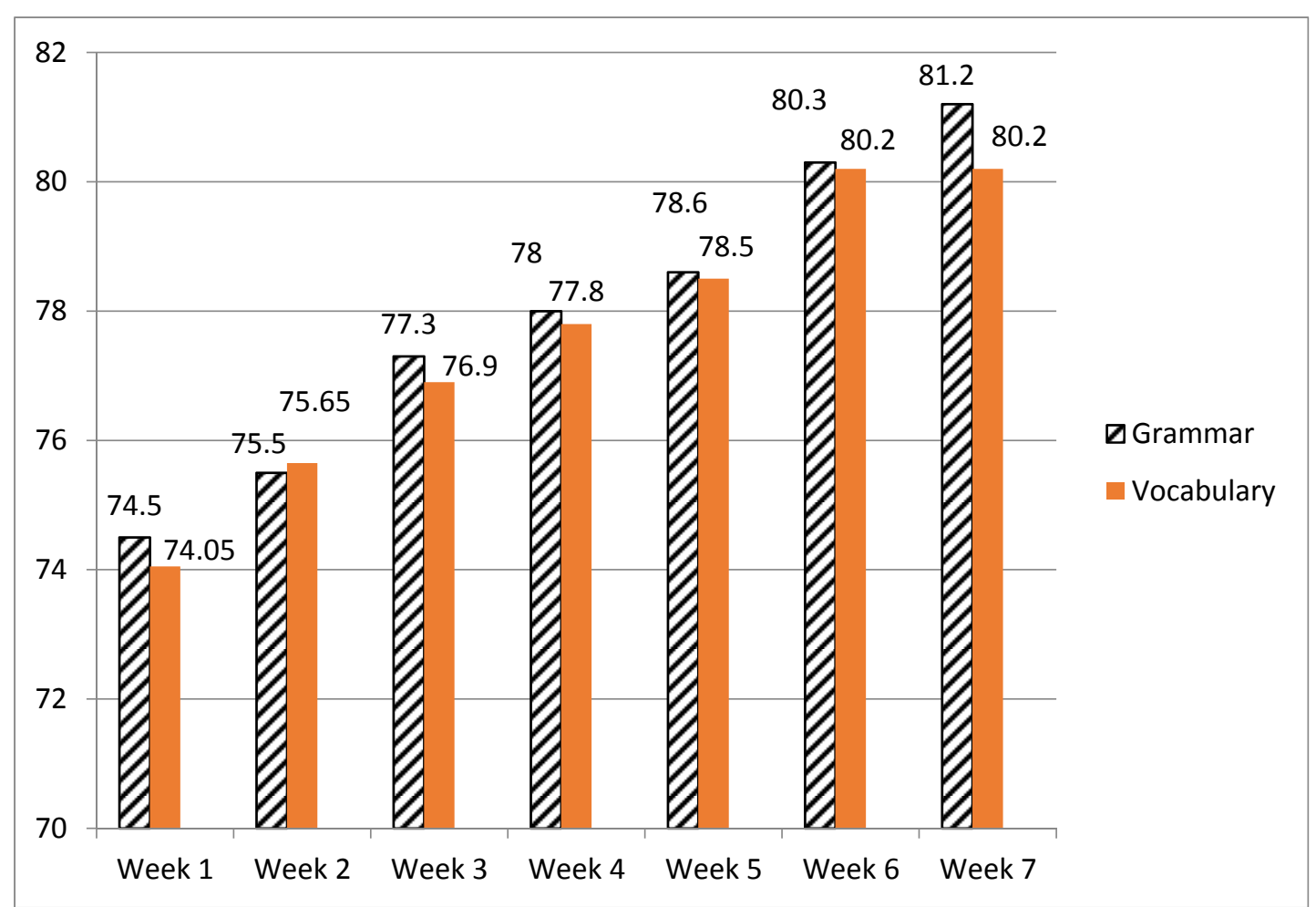

Figure 9. Averages of subjects in the control group with form-focused instruction in all weeks

When weekly achievements of learners are examined, it is clearly seen that control group with form-focused instruction increased their scores gradually weekly and, learners in the form-focused group had better results in weekly examinations.

However learners in the meaning-focused group had not worse but constant results in weekly examinations. It is clearly seen that form-focused reading is more useful for upper-intermediate level learners in the study.

Samples in this study are upper-intermediate level learners, so this study yields that form-focused reading is more useful for learners whose level of language is high. Form-focused reading is more useful for learners whose level of language is low.

All charts allowed observing the progress of the learners better. Pre-test and post-test (which involved all language skills) analysis were carried out as well. Averages of learners in these tests were calculated and their achievement was shown in a chart.

Before the reading program started, learners in both groups had a first pre-test of FCE.

This first step that pre-test was important to know the levels of learners in the English language and to follow-up and compare their scores in second post-test during the reading program.

As FCE results are out of 200 points, the original data had to be recalculated, to make them comparable to hundreds of scale results for better understanding and more clarity of results : the average scores was divided by two, while the results for each contributing skill was divided by 10 . The recalculated results are shown in tables $23,25,27,29$. 
Table 22. Pre-Test: Original first FCE results of control group

\begin{tabular}{lllllll}
\hline Name of the Students & $\begin{array}{l}\text { Reading } \\
(20 \%)\end{array}$ & $\begin{array}{l}\text { Writing } \\
(20 \%)\end{array}$ & $\begin{array}{l}\text { Use of English } \\
(20 \%)\end{array}$ & $\begin{array}{l}\text { Listening } \\
(20 \%)\end{array}$ & $\begin{array}{l}\text { Speaking } \\
(20 \%)\end{array}$ & $\begin{array}{l}\text { Average FCI } \\
\text { Score }\end{array}$ \\
\hline Student 1 & 186 & 180 & 178 & 177 & 178 & 180 \\
Student 2 & 185 & 181 & 176 & 174 & 176 & 178 \\
Student 3 & 180 & 176 & 186 & 171 & 173 & 177 \\
Student 4 & 179 & 174 & 173 & 172 & 182 & 176 \\
Student 5 & 181 & 177 & 174 & 172 & 174 & 176 \\
Student 6 & 180 & 176 & 173 & 173 & 171 & 175 \\
Student 7 & 178 & 172 & 172 & 172 & 171 & 173 \\
Student 8 & 176 & 163 & 171 & 174 & 172 & 171 \\
Student 9 & 178 & 164 & 172 & 171 & 170 & 171 \\
Student 10 & 175 & 161 & 171 & 170 & 170 & 169 \\
Student 11 & 174 & 162 & 170 & 169 & 169 & 169 \\
Student 12 & 172 & 159 & 169 & 168 & 168 & 167 \\
Student 13 & 167 & 157 & 167 & 167 & 176 & 167 \\
Student 14 & 172 & 158 & 168 & 167 & 167 & 166 \\
Student 15 & 173 & 160 & 162 & 168 & 163 & 165 \\
Student 16 & 162 & 154 & 164 & 165 & 165 & 162 \\
Student 17 & 162 & 153 & 171 & 162 & 161 & 162 \\
Student 18 & 158 & 151 & 160 & 159 & 159 & 157 \\
Student 19 & 157 & 147 & 157 & 158 & 158 & 155 \\
Student 20 & 156 & 145 & 154 & 155 & 157 & 153 \\
Mean/Score out of 200 & $\mathbf{1 7 3}$ & $\mathbf{1 6 4}$ & $\mathbf{1 6 9}$ & $\mathbf{1 6 8}$ & $\mathbf{1 6 9}$ & $\mathbf{1 6 9}$ \\
\hline & & & & & & \\
\hline
\end{tabular}

Table 23. Pre-Test: First FCE recalculated results of control group

\begin{tabular}{lllllll}
\hline Name of the Students & $\begin{array}{l}\text { Reading } \\
(20 \%)\end{array}$ & $\begin{array}{l}\text { Writing } \\
(20 \%)\end{array}$ & $\begin{array}{l}\text { Use of English } \\
(20 \%)\end{array}$ & $\begin{array}{l}\text { Listening } \\
(20 \%)\end{array}$ & $\begin{array}{l}\text { Speaking } \\
(20 \%)\end{array}$ & $\begin{array}{l}\text { Score out } \\
\text { of } 100\end{array}$ \\
\hline Student 1 & 18.6 & 18 & 17.8 & 17.7 & 17.8 & 89.9 \\
Student 2 & 18.5 & 18.1 & 17.6 & 17.4 & 17.6 & 89.2 \\
Student 3 & 18 & 17.6 & 18.6 & 17.1 & 17.3 & 88.6 \\
Student 4 & 17.9 & 17.4 & 17.3 & 17.2 & 18.2 & 88 \\
Student 5 & 18.1 & 17.7 & 17.4 & 17.2 & 17.4 & 87.8 \\
Student 6 & 18 & 17.6 & 17.3 & 17.3 & 17.1 & 87.3 \\
Student 7 & 17.8 & 17.2 & 17.2 & 17.2 & 17.1 & 86.5 \\
Student 8 & 17.6 & 16.3 & 17.1 & 17.4 & 17.2 & 85.6 \\
Student 9 & 17.8 & 16.4 & 17.2 & 17.1 & 17 & 85.5 \\
Student 10 & 17.5 & 16.1 & 17.1 & 17 & 17 & 84.7 \\
Student 11 & 17.4 & 16.2 & 17 & 16.9 & 16.9 & 84.4 \\
Student 12 & 17.2 & 15.9 & 16.9 & 16.8 & 16.8 & 83.6 \\
Student 13 & 16.7 & 15.7 & 16.7 & 16.7 & 17.6 & 83.4 \\
Student 14 & 17.2 & 15.8 & 16.8 & 16.7 & 16.7 & 83.2 \\
Student 15 & 17.3 & 16 & 16.2 & 16.8 & 16.3 & 82.6 \\
Student 16 & 16.2 & 15.4 & 16.4 & 16.5 & 16.5 & 81 \\
Student 17 & 16.2 & 15.3 & 17.1 & 16.2 & 16.1 & 80.9 \\
Student 18 & 15.8 & 15.1 & 16 & 15.9 & 15.9 & 78.7 \\
Student 19 & 15.7 & 14.7 & 15.7 & 15.8 & 15.8 & 77.7 \\
Student 20 & 15.6 & 14.5 & 15.4 & 15.5 & 15.7 & 76.7 \\
Mean/Score out of 100 & $\mathbf{1 7 . 3}$ & $\mathbf{1 6 . 4}$ & $\mathbf{1 6 . 9}$ & $\mathbf{1 6 . 8}$ & $\mathbf{1 6 . 9}$ & $\mathbf{8 4 . 3}$ \\
\hline
\end{tabular}


Table 24. Pre-Test: Original first FCE results of experimental group

\begin{tabular}{lllllll}
\hline Name of the Students & $\begin{array}{l}\text { Reading } \\
(20 \%)\end{array}$ & $\begin{array}{l}\text { Writing } \\
(20 \%)\end{array}$ & $\begin{array}{l}\text { Use of English } \\
(20 \%)\end{array}$ & $\begin{array}{l}\text { Listening } \\
(20 \%)\end{array}$ & $\begin{array}{l}\text { Speaking } \\
(20 \%)\end{array}$ & $\begin{array}{l}\text { Average FCI } \\
\text { Score }\end{array}$ \\
\hline Student 1 & 185 & 181 & 176 & 174 & 176 & 178 \\
Student 2 & 181 & 181 & 178 & 177 & 188 & 181 \\
Student 3 & 181 & 177 & 174 & 172 & 154 & 172 \\
Student 4 & 180 & 176 & 186 & 171 & 173 & 177 \\
Student 5 & 178 & 172 & 172 & 172 & 171 & 173 \\
Student 6 & 178 & 164 & 172 & 171 & 166 & 170 \\
Student 7 & 176 & 143 & 171 & 174 & 172 & 167 \\
Student 8 & 175 & 161 & 171 & 170 & 170 & 169 \\
Student 9 & 175 & 162 & 170 & 169 & 169 & 169 \\
Student 10 & 173 & 160 & 162 & 168 & 163 & 165 \\
Student 11 & 172 & 159 & 169 & 158 & 168 & 165 \\
Student 12 & 172 & 155 & 158 & 166 & 167 & 164 \\
Student 13 & 171 & 173 & 171 & 172 & 182 & 174 \\
Student 14 & 167 & 160 & 167 & 167 & 146 & 161 \\
Student 15 & 162 & 154 & 164 & 165 & 165 & 162 \\
Student 16 & 162 & 153 & 171 & 162 & 161 & 162 \\
Student 17 & 158 & 151 & 160 & 159 & 159 & 157 \\
Student 18 & 156 & 145 & 154 & 155 & 157 & 153 \\
Student 19 & 155 & 147 & 157 & 158 & 158 & 155 \\
Student 20 & 150 & 176 & 173 & 173 & 171 & 169 \\
Mean/Score out of 200 & $\mathbf{1 7 0}$ & $\mathbf{1 6 3}$ & $\mathbf{1 6 9}$ & $\mathbf{1 6 8}$ & $\mathbf{1 6 7}$ & $\mathbf{1 6 7}$ \\
\hline & & & & & & \\
\hline
\end{tabular}

Table 25. Pre-Test: First FCE recalculated results of experimental group

\begin{tabular}{lllllll}
\hline Name of the Students & $\begin{array}{l}\text { Reading } \\
(20 \%)\end{array}$ & $\begin{array}{l}\text { Writing } \\
(20 \%)\end{array}$ & $\begin{array}{l}\text { Use of English } \\
(20 \%)\end{array}$ & $\begin{array}{l}\text { Listening } \\
(20 \%)\end{array}$ & $\begin{array}{l}\text { Speaking } \\
(20 \%)\end{array}$ & Score out of 100 \\
\hline Student 1 & 18.6 & 18.1 & 17.6 & 17.4 & 17.6 & 89.3 \\
Student 2 & 18.1 & 18.1 & 17.8 & 17.7 & 18.8 & 90.5 \\
Student 3 & 18.1 & 17.7 & 17.4 & 17.2 & 15.4 & 85.8 \\
Student 4 & 18 & 17.6 & 18.6 & 17.1 & 17.3 & 88.6 \\
Student 5 & 17.8 & 17.2 & 17.2 & 17.2 & 17.1 & 86.5 \\
Student 6 & 17.8 & 16.4 & 17.2 & 17.1 & 16.6 & 85.1 \\
Student 7 & 17.6 & 14.3 & 17.1 & 17.4 & 17.2 & 83.6 \\
Student 8 & 17.5 & 16.1 & 17.1 & 17 & 17 & 84.7 \\
Student 9 & 17.5 & 16.2 & 17 & 16.9 & 16.9 & 84.5 \\
Student 10 & 17.3 & 16 & 16.2 & 16.8 & 16.3 & 82.6 \\
Student 11 & 17.2 & 15.9 & 16.9 & 15.8 & 16.8 & 82.6 \\
Student 12 & 17.2 & 15.5 & 15.8 & 16.6 & 16.7 & 81.8 \\
Student 13 & 17.1 & 17.3 & 17.1 & 17.2 & 18.2 & 86.9 \\
Student 14 & 16.7 & 16 & 16.7 & 16.7 & 14.6 & 80.7 \\
Student 15 & 16.2 & 15.4 & 16.4 & 16.5 & 16.5 & 81 \\
Student 16 & 16.2 & 15.3 & 17.1 & 16.2 & 16.1 & 80.9 \\
Student 17 & 15.8 & 15.1 & 16 & 15.9 & 15.9 & 78.7 \\
Student 18 & 15.6 & 14.5 & 15.4 & 15.5 & 15.7 & 76.7 \\
Student 19 & 15.5 & 14.7 & 15.7 & 15.8 & 15.8 & 77.5 \\
Student 20 & 15 & 17.6 & 17.3 & 17.3 & 17.1 & 84.3 \\
Mean/Score out of 100 & $\mathbf{1 7 . 0}$ & $\mathbf{1 6 . 3}$ & $\mathbf{1 6 . 9}$ & $\mathbf{1 6 . 8}$ & $\mathbf{1 6 . 7}$ & $\mathbf{8 3 . 7}$ \\
\hline
\end{tabular}




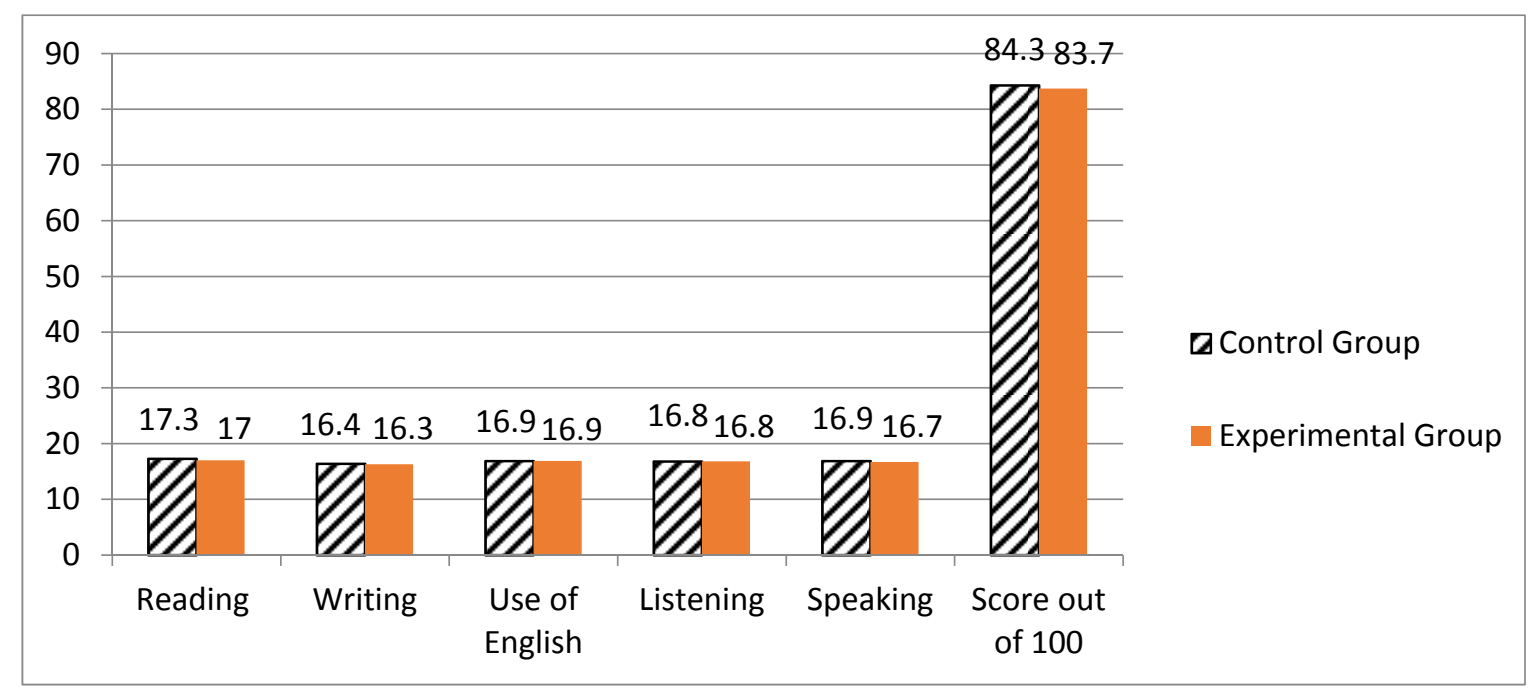

Figure 10. Pre-test of FCE: Averages of all learners in both groups

\section{Post-Test}

At the end of seven-week program, we applied another FCE exam to compare the results with the pre-test FCE exam. The results are shown below.

Table 26. Post-Test: Original Second FCE results of control group

\begin{tabular}{lllllll}
\hline Name of the Students & $\begin{array}{l}\text { Reading } \\
(20 \%)\end{array}$ & $\begin{array}{l}\text { Writing } \\
(20 \%)\end{array}$ & $\begin{array}{l}\text { Use of English } \\
(20 \%)\end{array}$ & $\begin{array}{l}\text { Listening } \\
(20 \%)\end{array}$ & $\begin{array}{l}\text { Speaking } \\
(20 \%)\end{array}$ & Average FCI Score \\
\hline Student 1 & 197 & 184 & 178 & 180 & 188 & 185 \\
Student 2 & 192 & 173 & 161 & 162 & 171 & 172 \\
Student 3 & 188 & 174 & 181 & 170 & 172 & 177 \\
Student 4 & 185 & 165 & 161 & 166 & 164 & 168 \\
Student 5 & 184 & 196 & 179 & 172 & 171 & 180 \\
Student 6 & 183 & 179 & 176 & 188 & 176 & 180 \\
Student 7 & 182 & 178 & 183 & 175 & 173 & 178 \\
Student 8 & 181 & 182 & 174 & 182 & 174 & 179 \\
Student 9 & 180 & 176 & 173 & 173 & 171 & 175 \\
Student 10 & 179 & 175 & 174 & 183 & 180 & 178 \\
Student 11 & 178 & 185 & 172 & 171 & 170 & 175 \\
Student 12 & 178 & 174 & 171 & 170 & 171 & 173 \\
Student 13 & 176 & 176 & 170 & 169 & 184 & 175 \\
Student 14 & 175 & 170 & 191 & 168 & 169 & 175 \\
Student 15 & 174 & 177 & 169 & 168 & 168 & 171 \\
Student 16 & 174 & 178 & 167 & 167 & 166 & 170 \\
Student 17 & 173 & 168 & 168 & 167 & 167 & 169 \\
Student 18 & 167 & 164 & 164 & 165 & 165 & 165 \\
Student 19 & 165 & 171 & 175 & 189 & 169 & 174 \\
Student 20 & 158 & 166 & 167 & 158 & 158 & 161 \\
Mean / Score out of 200 & $\mathbf{1 7 8 . 4}$ & $\mathbf{1 7 5 . 5}$ & $\mathbf{1 7 2 . 7}$ & $\mathbf{1 7 2 . 1}$ & $\mathbf{1 7 1 . 3}$ & $\mathbf{1 7 4 . 0 4}$ \\
\hline
\end{tabular}


Table 27. Post-Test: Second FCE recalculated results of control group

\begin{tabular}{lllllll}
\hline Name of the Students & $\begin{array}{l}\text { Reading } \\
(20 \%)\end{array}$ & $\begin{array}{l}\text { Writing } \\
(20 \%)\end{array}$ & $\begin{array}{l}\text { Use of English } \\
(20 \%)\end{array}$ & $\begin{array}{l}\text { Listening } \\
(20 \%)\end{array}$ & $\begin{array}{l}\text { Speaking } \\
(20 \%)\end{array}$ & $\begin{array}{l}\text { Score out } \\
\text { of } 100\end{array}$ \\
\hline Student 1 & 19.7 & 18.4 & 17.8 & 18 & 18.8 & 92.7 \\
Student 2 & 19.2 & 17.3 & 16.1 & 16.2 & 17.1 & 85.9 \\
Student 3 & 18.8 & 17.4 & 18.1 & 17 & 17.2 & 88.5 \\
Student 4 & 18.5 & 16.5 & 16.1 & 16.6 & 16.4 & 84.1 \\
Student 5 & 18.4 & 19.6 & 17.9 & 17.2 & 17.1 & 90.2 \\
Student 6 & 18.3 & 17.9 & 17.6 & 18.8 & 17.6 & 90.2 \\
Student 7 & 18.2 & 17.8 & 18.3 & 17.5 & 17.3 & 89.1 \\
Student 8 & 18.1 & 18.2 & 17.4 & 18.2 & 17.4 & 89.3 \\
Student 9 & 18 & 17.6 & 17.3 & 17.3 & 17.1 & 87.3 \\
Student 10 & 17.9 & 17.5 & 17.4 & 18.3 & 18 & 89.1 \\
Student 11 & 17.8 & 18.5 & 17.2 & 17.1 & 17 & 87.6 \\
Student 12 & 17.8 & 17.4 & 17.1 & 17 & 17.1 & 86.4 \\
Student 13 & 17.6 & 17.6 & 17 & 16.9 & 18.4 & 87.5 \\
Student 14 & 17.5 & 17 & 19.1 & 16.8 & 16.9 & 87.3 \\
Student 15 & 17.4 & 17.7 & 16.9 & 16.8 & 16.8 & 85.6 \\
Student 16 & 17.4 & 17.8 & 16.7 & 16.7 & 16.6 & 85.2 \\
Student 17 & 17.3 & 16.8 & 16.8 & 16.7 & 16.7 & 84.3 \\
Student 18 & 16.7 & 16.4 & 16.4 & 16.5 & 16.5 & 82.5 \\
Student 19 & 16.5 & 17.1 & 17.5 & 18.9 & 16.9 & 86.9 \\
Student 20 & 15.8 & 16.6 & 16.7 & 15.8 & 15.8 & 80.7 \\
Mean /Score out of 100 & $\mathbf{1 7 . 8}$ & $\mathbf{1 7 . 6}$ & $\mathbf{1 7 . 3}$ & $\mathbf{1 7 . 2}$ & $\mathbf{1 7 . 1}$ & $\mathbf{8 7 . 0}$ \\
\hline
\end{tabular}

Table 28. Post-Test: Original Second FCE results of experimental group

\begin{tabular}{lllllll}
\hline Name of the Students & $\begin{array}{l}\text { Reading } \\
(20 \%)\end{array}$ & $\begin{array}{l}\text { Writing } \\
(20 \%)\end{array}$ & $\begin{array}{l}\text { Use of English } \\
(20 \%)\end{array}$ & $\begin{array}{l}\text { Listening } \\
(20 \%)\end{array}$ & $\begin{array}{l}\text { Speaking } \\
(20 \%)\end{array}$ & $\begin{array}{l}\text { Average FCI } \\
\text { Score }\end{array}$ \\
\hline Student 1 & 188 & 196 & 197 & 169 & 168 & 184 \\
Student 2 & 197 & 194 & 188 & 198 & 198 & 195 \\
Student 3 & 184 & 196 & 179 & 178 & 189 & 185 \\
Student 4 & 188 & 191 & 178 & 189 & 176 & 184 \\
Student 5 & 195 & 189 & 191 & 188 & 182 & 189 \\
Student 6 & 192 & 188 & 183 & 177 & 193 & 187 \\
Student 7 & 184 & 182 & 184 & 189 & 184 & 185 \\
Student 8 & 185 & 178 & 174 & 188 & 185 & 182 \\
Student 9 & 188 & 176 & 191 & 194 & 178 & 185 \\
Student 10 & 178 & 188 & 177 & 187 & 169 & 180 \\
Student 11 & 185 & 185 & 191 & 192 & 194 & 189 \\
Student 12 & 198 & 191 & 175 & 189 & 189 & 188 \\
Student 13 & 178 & 185 & 192 & 175 & 177 & 181 \\
Student 14 & 189 & 196 & 182 & 185 & 178 & 186 \\
Student 15 & 186 & 176 & 190 & 189 & 184 & 185 \\
Student 16 & 192 & 193 & 185 & 182 & 171 & 185 \\
Student 17 & 178 & 194 & 191 & 186 & 171 & 184 \\
Student 18 & 184 & 187 & 189 & 168 & 168 & 179 \\
Student 19 & 175 & 183 & 184 & 175 & 185 & 180 \\
Student 20 & 183 & 184 & 188 & 177 & 187 & 184 \\
Mean/Score out of 200 & $\mathbf{1 8 6}$ & $\mathbf{1 8 8}$ & $\mathbf{1 8 5}$ & $\mathbf{1 8 4}$ & $\mathbf{1 8 1}$ & $\mathbf{1 8 5}$ \\
\hline
\end{tabular}


Table 29. Post-Test: Second FCE recalculated results of experimental group

\begin{tabular}{lllllll}
\hline Name of the Students & $\begin{array}{l}\text { Reading } \\
(20 \%)\end{array}$ & $\begin{array}{l}\text { Writing } \\
(20 \%)\end{array}$ & $\begin{array}{l}\text { Use of English } \\
(20 \%)\end{array}$ & $\begin{array}{l}\text { Listening } \\
(20 \%)\end{array}$ & $\begin{array}{l}\text { Speaking } \\
(20 \%)\end{array}$ & $\begin{array}{l}\text { Score out of } \\
100\end{array}$ \\
\hline Student 1 & 18.8 & 19.6 & 19.7 & 16.9 & 16.8 & 91.8 \\
Student 2 & 19.7 & 19.4 & 18.8 & 19.8 & 19.8 & 97.5 \\
Student 3 & 18.4 & 19.6 & 17.9 & 17.8 & 18.9 & 92.6 \\
Student 4 & 18.8 & 19.1 & 17.8 & 18.9 & 17.6 & 92.2 \\
Student 5 & 19.5 & 18.9 & 19.1 & 18.8 & 18.2 & 94.5 \\
Student 6 & 19.2 & 18.8 & 18.3 & 17.7 & 19.3 & 93.3 \\
Student 7 & 18.4 & 18.2 & 18.4 & 18.9 & 18.4 & 92.3 \\
Student 8 & 18.5 & 17.8 & 17.4 & 18.8 & 18.5 & 91 \\
Student 9 & 18.8 & 17.6 & 19.1 & 19.4 & 17.8 & 92.7 \\
Student 10 & 17.8 & 18.8 & 17.7 & 18.7 & 16.9 & 89.9 \\
Student 11 & 18.5 & 18.5 & 19.1 & 19.2 & 19.4 & 94.7 \\
Student 12 & 19.8 & 19.1 & 17.5 & 18.9 & 18.9 & 94.2 \\
Student 13 & 17.8 & 18.5 & 19.2 & 17.5 & 17.7 & 90.7 \\
Student 14 & 18.9 & 19.6 & 18.2 & 18.5 & 17.8 & 93 \\
Student 15 & 18.6 & 17.6 & 19 & 18.9 & 18.4 & 92.5 \\
Student 16 & 19.2 & 19.3 & 18.5 & 18.2 & 17.1 & 92.3 \\
Student 17 & 17.8 & 19.4 & 19.1 & 18.6 & 17.1 & 92 \\
Student 18 & 18.4 & 18.7 & 18.9 & 16.8 & 16.8 & 89.6 \\
Student 19 & 17.5 & 18.3 & 18.4 & 17.5 & 18.5 & 90.2 \\
Student 20 & 18.3 & 18.4 & 18.8 & 17.7 & 18.7 & 91.9 \\
Mean/Score out of 100 & $\mathbf{1 8 . 6}$ & $\mathbf{1 8 . 8}$ & $\mathbf{1 8 . 5}$ & $\mathbf{1 8 . 4}$ & $\mathbf{1 8 . 1}$ & $\mathbf{9 2 . 4}$ \\
\hline
\end{tabular}

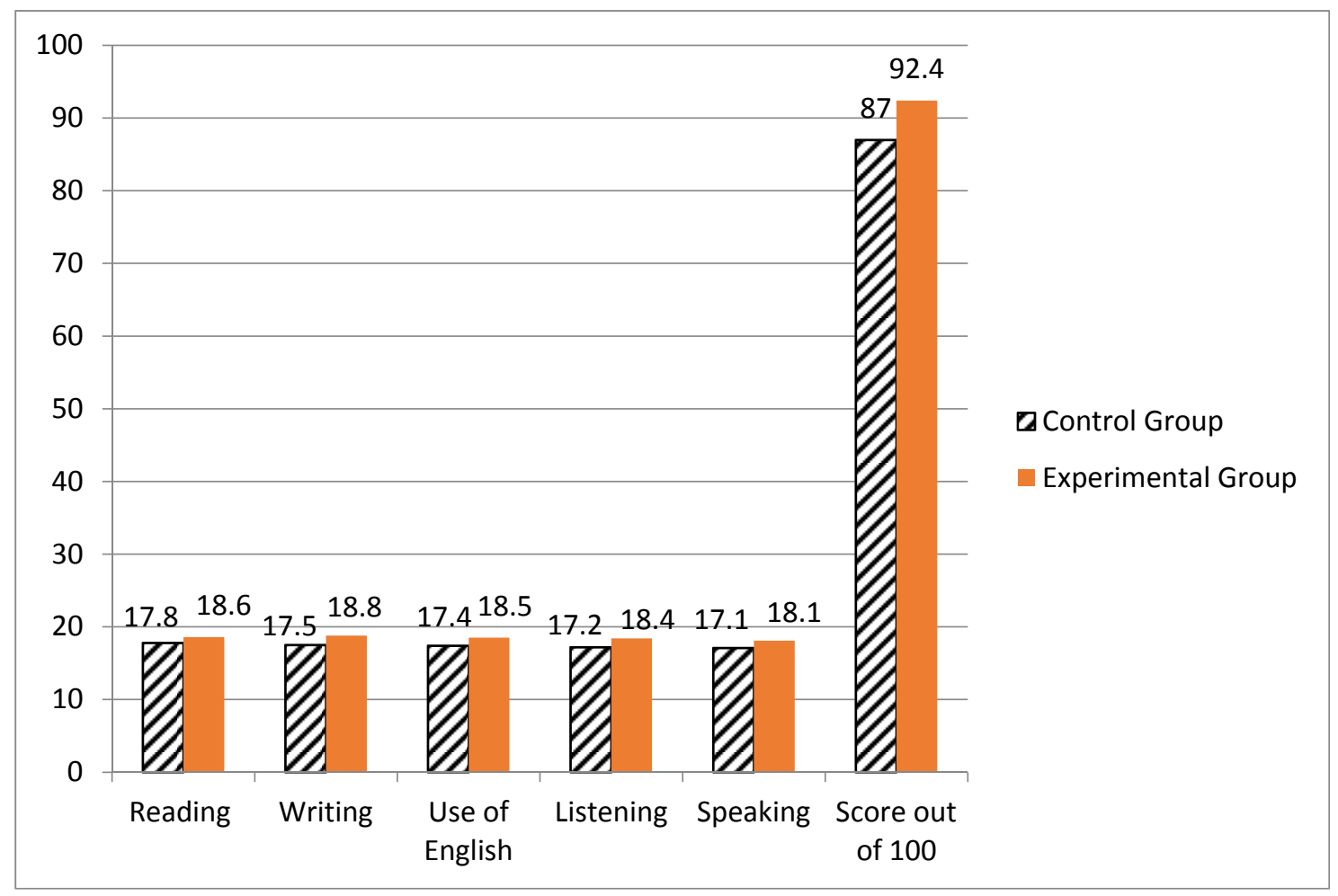

Figure 11. Post-test of FCE: Averages of all learners in both groups 


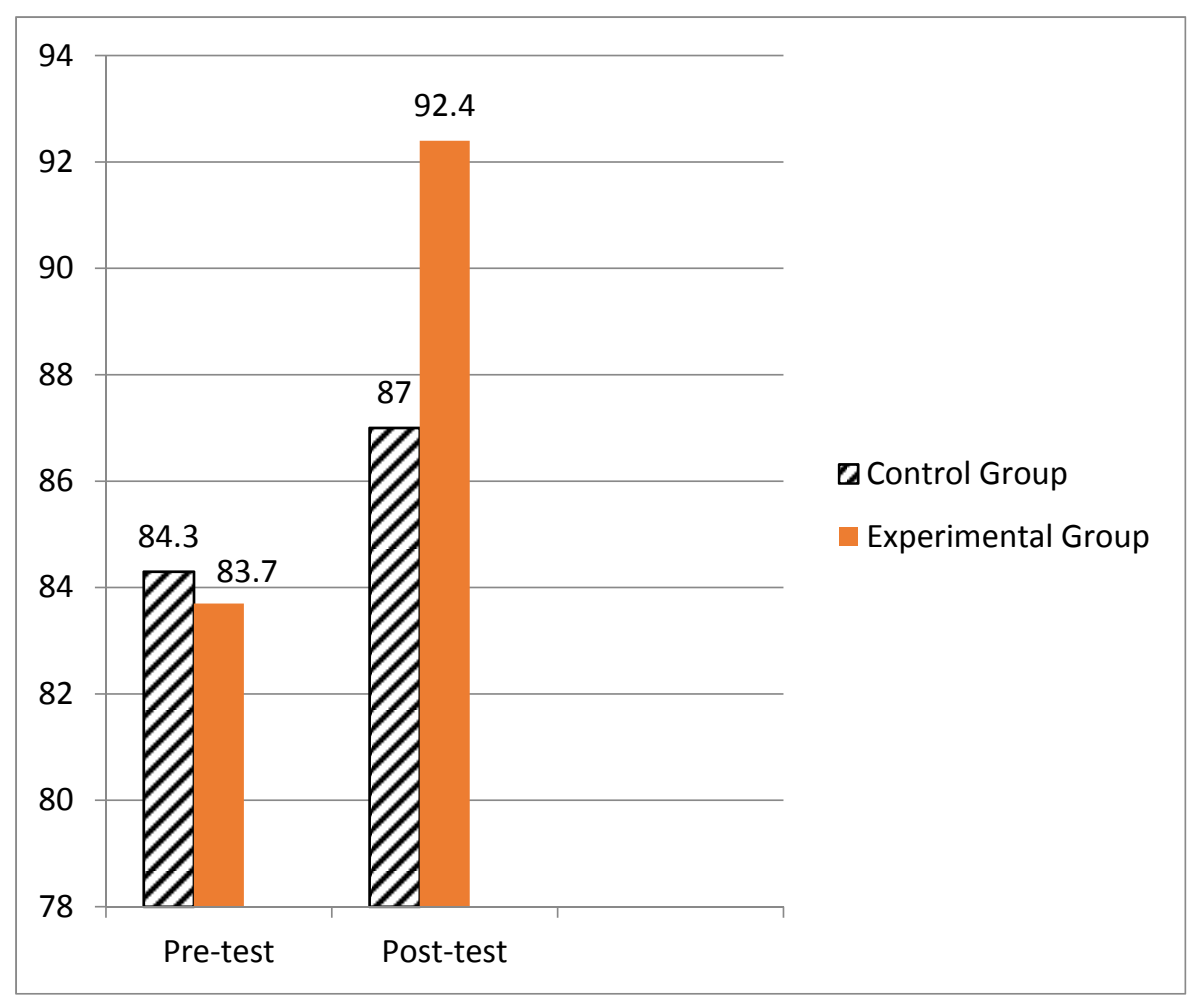

Figure 12. Average scores of Pre-test FCE and Post-test FCE

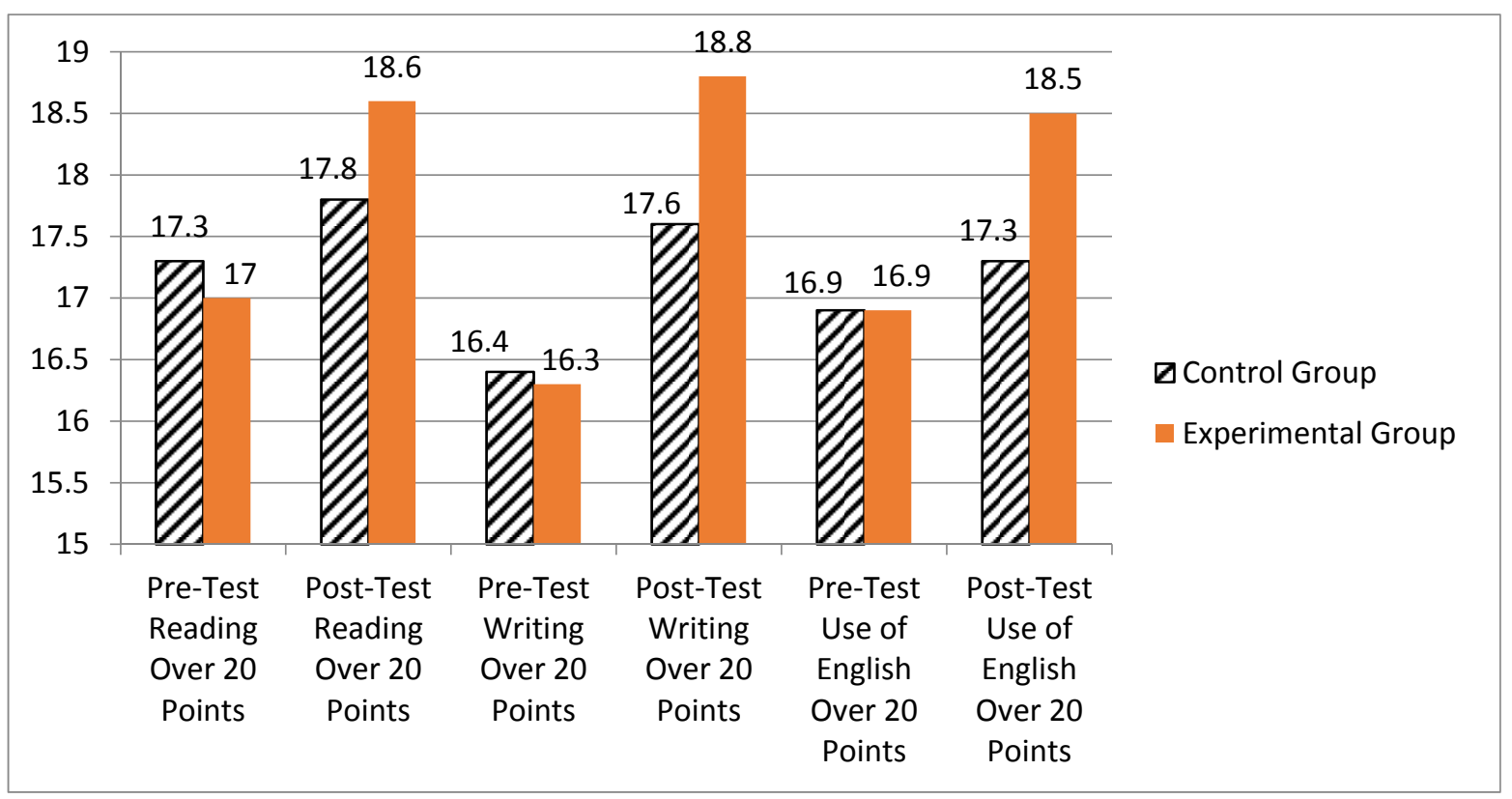

Figure 13. Reading, writing and use of English sections of average scores in Pre-test FCE and Post-test FCE

This figure gives very clear picture of the development of the two groups. The results especially changed in reading, writing and the use of English parts. Although the results were very close to each other in two groups in pre-test, there seems to come out clearly observable differences between two groups in post-test FCE exam.

\section{Conclusion}

At the end of the seven weeks, we evaluated the results by comparing the numeric data we obtained and comparing them with what was already put forth by the researchers. Meaning-focused instruction was said to 
promote learning because of meaningful tasks (Gardner, D. \& Wood, R. (2009). In our doctoral disseration, we concluded that form-focused and meaning-focused instruction do not have considerable differences in pre-intermediate level. But in this study, some different conclusions emerged. Since the structures and the vocabulary are much more difficult in upper-intermediate level, students generally needed to receive necessary instructions to fully comprehend and get the correct uses of words. The FCE exam measures the level of upper-intermediate students and it asks some special collocations and words with different uses. For instance, it asks verbs and adjectives with their prepositions and some structures that the students can never see in previous levels. When such words are not highlighted and the complex structures are not given with their true meaning, the students cannot notice them just in meaningful context solely. As a result, we concluded that the students did not get the desired results as sufficiently with meaning-focused instruction. As for the group with form-focused instruction, they got better results in the FCE test because they were given the structures and the vocabulary clearly with the instructor's special focus.

Although there are not considerable differences between form-focused and meaning-focused instruction in early levels as it was shown in our doctoral dissertation, this study shows that the students getting form-focused instruction tend to do better in a selective exam like FCE and they learn slightly better in this way. It can also be stated that meaning-focused instruction slightly slows down the learning process in upper-intermediate level.

At the beginning, the results of the two groups were quite similar, but in time, the control group bettered off during seven weeks and the experiment groups did not get any considerable improvement. The final FCE test indicated how the students improved and the results give a clear picture of their development.

\section{References}

Allen, S. (1977). Mind Your Language. London Weekend Television. Retrieved from https://www.youtube.com/watch?v=Bsn3MT-5Yyo\&t=72s

Canagarajah, A. S. (1996). Appropriate methodology and social context. ELT Journal, 50(1). https://doi.org/10.1093/elt/50.1.80

Celce-Muncia, M., Dornyei, Z., \& Thurrell, S. (1997). Direct Approach to L2 Instruction: A Turning Point in Communicative Language Teaching? TESOL Quarterly, 31, 141-152. https://doi.org/10.2307/3587979

Çelik, B. (2016). The Role of Extensive Reading in Supporting English as a Foreign Language (EFL) Students to Master English Language Vocabulary and Grammar (A Case Study of Ishik University Preparatory School in Iraq). International Black Sea University Faculty Of Education And Humanities PhD Program In Education Sciences, Tbilisi.

Doughty, C., \& Williams, J. (1998). Pedagogical choices in focus on form. In C. Doughty \& J. Williams (Eds.), Focus on form in classroom second language acquisition (pp. 197-261). Cambridge: Cambridge University Press

Ellis, R. (2001). Investigating form-focused instruction. In R. Ellis (Ed.), Form Focused Instruction in Second Language Learning. Oxford: Blackwell.

Ellis, R., Basturkmen, H., \& Loewen, S. (2002). Doing focus on form. System, 30, 420. https://doi.org/10.1016/S0346-251X (02)00047-7

Gardner, D., \& Wood, R. (2009). Errors, Feedback, Learning and Performance. The Australian and New Zealand Journal of Organisational Psychology, 2, 30-43. https://doi.org/10.1375/ajop.2.1.30

Göksu, A. (2014). The Effects Of Corrective Feedback On The Grammar Acquisition Of Young Learners Through The Focus-On-Form Instruction In An Efl Context. Gazi University Institute Of Educational Sciences, Department Of Foreign Languages Education, Doctoral Dissertation, Ankara.

Grim, F. M. A. (2005). The integration of Focus-on-Form instruction within culture-based lessons: Its effects on students' performance on knowledge of vocabulary, grammar, and culture in 2nd and 3rd semester French courses. Unpublished Doctoral Dissertation, University of Illinois, USA.

Gündüz, Z. E., Akcan, S., \& Bayyurt, Y. (2012) Isolated form focused instruction and integrated Form-Focused Instruction in primary school English classrooms in Turkey. Language, Culture and Curriculum, 25(2), 157-171.

Holliday, A. (1994). Appropriate Methodology and Social Context. Cambridge: Cambridge University Press. https://doi.org/10.1080/07908318.2012.683008

Krashen, S. (1988). The Input Hypothesis: Issues and Implications. London: Longman. 
Krashen, S. D. (1985). The input hypothesis: Issues and implications. New York: Longman

Lamb, M. (1995). The consequence s of INSET. ELT Journal, 49(1), 72-80. https://doi.org/10.1093/elt/49.1.72

Larsen-Freeman, D., \& Long, M. H. (2014). An Introduction to Second Language Acquisition Research. London and New York: Routledge.

Littlewood, W. (1980). Form and Meaning in Language Teaching Methodology. The Modern Language Journal, 64(4), 441-445. https://doi.org/10.1111/j.1540-4781.1980.tb05220.x

Long, M. (1991). Focus on form: A design feature in language teaching methodology. In K. De Bot, R. Ginsberg \& C. Kramsch (Eds.), Foreign Language Research in Cross-cultural Perspective (pp. 39-52). Amsterdam: John Benjamins. https://doi.org/10.1075/sibil.2.07lon

Long, M. H. (2000). Focus on Form in Task Based Language Teaching. In R. D. Lambert \& E. Shohamy (Eds.), Language Policy and Pedagogy: Essays in Honor of A. Ronald Walton (pp. 179-191). Cambridge: Cambridge University Press. https://doi.org/10.1075/z.96.11lon

Long, M., \& Robinson, P. (1998). Focus on form: Theory, research, and practice. In C. Doughty \& J. Williams (Eds.), Focus on Form In Classroom Second Language Acquisition. Cambridge: Cambridge University Press.

Nassaji, H. (2000). Towards Integrating Form-Focused Instruction and Communicative Interaction in the Second Language Classroom: Some Pedagogical Possibilities. The Modern Language Journal, 84(2), https://doi.org/10.1111/0026-7902.00065

Nation, I. S. P. (2001). Learning Vocabulary in Another Language. Cambridge: Cambridge University Press.

O'Sullivan, M. C. (2001). Communicative Approaches to Teaching English in Namibia: The issue of transfer of Western approaches to developing countries. International Journal of Early Years Education, 9(1).

Richards, J. C., \& Rogers, T. (1986). Approaches and Methods in Language Teaching. Cambridge: Cambridge University Press.

Saeidi, M., Zaferanieh, E., \& Shatery, H. (2012). On the Effects of Focus on Form, Focus on Meaning, and Focus on Forms on Learners' Vocabulary Learning in ESP Context. English Language Teaching, 5(10). https://doi.org/10.5539/elt.v5n10p72

Sheen, R. (2002). Focus-on-Form and Focus-on-Forms. ELT Journal, 56(3), 303-305. https://doi.org/10.1093/elt/56.3.303

Spada, N., \& Lightbown, P. M. (2008). Form-focused instruction: Isolated or integrated? TESOL Quarterly, 42(2), 181-207. https://doi.org/10.1002/j.1545-7249.2008.tb00115.x

Stern, H. H. (1992). The analytic-experiential dimen- sion. In P. Allen \& B. Harley (Eds.), Issues and options in language teaching (pp. 301-326). Oxford: Oxford University Press.

Thompson, G. (1996). Some misconceptions about communicative language teaching. ELT Journal, 50(1). https://doi.org/10.1093/elt/50.1.9

Yang, Y., \& Lyster, R. (2010). Effects of form-focused practice and feedback on Chinese EFL learners' acquisition of regular and irregular past tense forms. Studies in Second Language Acquisition, 32(2), 235-263. https://doi.org/10.1017/S0272263109990519

\section{Copyrights}

Copyright for this article is retained by the author, with first publication rights granted to the journal.

This is an open-access article distributed under the terms and conditions of the Creative Commons Attribution license (http://creativecommons.org/licenses/by/4.0/). 